\title{
Temporal variations in the feeding habits and trophic levels of three deep-sea demersal fishes from the western Mediterranean Sea, based on stomach contents and stable isotope analyses
}

\author{
E. Fanelli* ${ }^{*}$ J. E. Cartes \\ CSIC Institut de Ciénciès del Mar, Passeig Maritim de la Barceloneta 37-49, 08003 Barcelona, Spain
}

\begin{abstract}
Temporal variations in feeding habits and trophic levels of 3 deep-sea fishes: Hoplostethus mediterraneus, Hymenocephalus italicus and Nezumia aequalis, were investigated off the Archipelago of Cabrera (Algerian Basin). These species are representative of the 3 main trophic guilds found at bathyal depths: plankton feeders, suprabenthos feeders and epi-endobenthos feeders. Samples were collected during 6 trawl surveys at bi-monthly intervals from August 2003 to June 2004, between 550 and $750 \mathrm{~m}$ depths. Stomach content and stable isotope analyses were performed to detect temporal variations in diet. Because fish were immediately fixed in $10 \%$ formalin, a parallel experiment comparing isotope composition in fixed and freshly frozen tissues was carried out. $H$. mediterraneus mainly preyed on isopods throughout the sampling period and to a lesser extent on amphipods and mysids, although mixing models revealed high consumption of mesopelagic fish in winter and spring. H. italicus fed on mysids and amphipods that live in the benthic boundary layer, while $N$. aequalis exhibited a more benthic diet composed of benthopelagic and benthic prey (e.g. tanaids and polychaetes). Temporal variation was observed in the diet of $H$. mediterraneus, with February being the period of change in feeding habits. Temporal changes were also evident, though weaker than in $H$. mediterraneus, in the diets of the 2 macrourids, H. italicus and N. aequalis. Patterns of temporal change in fish diets follow temporal variations in prey, which are stronger in mesopelagic than in suprabenthic or benthic fauna. Temporal variations in tissue $\delta^{15} \mathrm{~N}$ were detected in the 3 species, with the lowest values occurring in September and the highest in April to June. In general, different time lags were detected between the isotopic turnover time of consumers and that of their diets (prey) at a monthly time scale, showing that assimilation times depend on species behaviour and metabolism. Assimilation times are brief in $H$. mediterraneus but last up to 2 mo in the benthic feeder $N$. aequalis. The experiment comparing fixed versus frozen tissues showed that formalin did not affect $\delta^{15} \mathrm{~N}$ values after 6,12 and 24 mo of preservation, while $\delta^{13} \mathrm{C}$ signatures were depleted to different extents in the 3 species compared with controls.
\end{abstract}

KEY WORDS: Hoplostethus mediterraneus $\cdot$ Hymenocephalus italicus $\cdot$ Nezumia aequalis $\cdot$ Stomach contents $\cdot$ Stable isotopes $\cdot$ Mixing models $\cdot$ Temporal variations $\cdot$ Formalin preservation

Resale or republication not permitted without written consent of the publisher

\section{INTRODUCTION}

Knowledge of the feeding ecology of marine animals is crucial to understand how an ecological system operates, and this is particularly true for deep-sea ecosystems, which are less known and increasingly exploited. At bathyal depths most of our knowledge on deep-sea demersal communities comes principally from areas where deep-water fisheries are developed.
In terms of dietary studies many deep-water fish populations of the Mediterranean Sea have been the subject of intensive research, particularly in the Balearic Basin (e.g. Macpherson 1981, Carrassón et al. 1992, Carrassón \& Matallanas 1998, 2002, Carrassón \& Cartes 2002), an area for which there is also a great deal of information available on decapod crustaceans.

The deep portion of the Mediterranean Sea has high stability with respect to temperature and salinity (Mar- 
galef 1985), and other conditions, such as the proportion of mud and organic matter content in sediments, also vary relatively little at mid-slope depths (Carpine 1970, Cartes et al. 2002). Therefore, this is a good ecosystem in which to study trophic relationships among the fauna, because of the relatively small influence of other environmental factors. The deep-sea environment was once thought to be quiet and calm, and lacking seasonal changes. However, several studies in recent decades have revealed that distinct seasonality exists in the marine life of the deep sea due to seasonal deposition of phytodetritus exported from the ocean surface (Gooday 1988, Thiel et al. 1989, Rice et al. 1994). Deep-sea organisms that rely on this phytodetritus as a food source have corresponding life cycles (i.e. non-continuous reproduction and/or peaks in the recruitment) and fluctuations in abundance and biomass (Billet et al. 1983, Thiel et al. 1989).

Although deep-sea fauna of the western Mediterranean basin is well known with substantial information available on specific aspects, only a few studies have addressed seasonal feeding cycles (e.g. Cartes 1994, Madurell \& Cartes 2005, Fanelli \& Cartes 2008), primarily because of the difficulty of collecting samples at these depths.

In addition, most deep-sea demersal fish are active predators, regarded as generalists (i.e. with highly diversified diets) and depend mainly on benthopelagic and mesopelagic prey (Mauchline \& Gordon 1986). Many deep-sea fishes show diel and seasonal feeding patterns (e.g. Macpherson 1980, Mauchline \& Gordon 1984, Blaber \& Bulman 1987, Priede et al. 1994, Atkinson 1995, Madurell \& Cartes 2005, 2006), which often have been related to the temporal vertical migrations of their mesopelagic prey (Atkinson 1995, Gartner et al. 1997). The benthic boundary layer (BBL, the zone that extends a few tens of metres into the water column immediately overlying the sea bed) macrofauna (mainly peracarid and decapod crustaceans) are a key compartment linking lower trophic levels and top predators such as fish (Cattrijsse et al. 1994, Cartes 1998, Carrassón \& Cartes 2002). However, despite the accepted role of this fauna in bathyal food webs, little is known about their interactions and dynamics.

In general, studies on feeding relationships of deepsea organisms have concentrated on gut contents. These data, however, have some limitations. For example, gut contents reflect diets at particular points in time and space, and neglect certain types of dietary materials such as gelatinous plankton and detritus that may nevertheless be important in sustaining marine food webs. Other limitations include the voiding of gut contents upon capture and the crushing or grinding of food that makes identification of prey difficult (Fanelli \& Cartes 2008). These limitations are especially intense in the study of food webs in the deep ocean, because of the constraints associated with sampling at great depths.

The use of stable isotopes of nitrogen $(\mathrm{N})$ and carbon (C) for the study of trophic interactions is now common in aquatic ecosystems (Pinnegar \& Polunin 2000). Analysis of stable isotope composition provides an indication of the origin and transformations of organic matter. Stable isotopes integrate short-term variations in diet and, thus, are less subject to temporal bias. In fish, tissue turnover rates may be as slow as 0.1 to $0.2 \%$ $\mathrm{d}^{-1}$ (Hesslein et al. 1993). The $\delta^{15} \mathrm{~N}$ in tissues of consumers is typically greater by 2 to $3 \%$ relative to their prey, so that stable $\mathrm{N}$-isotope data have been used to estimate the trophic levels of organisms (Owens 1988). In contrast, tissues tend to be rather weakly enriched in ${ }^{13} \mathrm{C}$ at progressively higher trophic levels $(<1 \%)$; thus, ${ }^{13} \mathrm{C}$ may act as a useful indicator of the primary organic carbon sources of an organism's diet. Stable isotopes have rarely been applied to detect seasonal changes in fish diet (Polunin et al. 2001, MacNeil et al. 2006), and applications of stable isotope analysis (SIA) in deep-sea ecosystems to elucidate temporal changes in trophic levels are scarce (Fanelli \& Cartes 2008, Madurell et al. 2008, Fanelli et al. 2009). Despite their advantages, results of SIA often need the knowledge of dietary composition from gut content analyses to be interpreted correctly, because isotope composition gives only an average indication of the trophic level of food that has been assimilated into tissues (see Johnston \& Kennedy, 1998 and Owens \& Watts 1998 for reviews). Hence, we chose to study stomach contents and stable isotopic composition simultaneously.

In this study we combined information on stomach contents of 3 deep-sea fishes: Hoplostethus mediterraneus, Hymenocephalus italicus and Nezumia aequalis, with stable isotope composition of predators and prey to test for (1) temporal variations in feeding habits and trophic levels of predators and (2) the lag between the isotopic turnover time of consumers and that of their diets at a seasonal scale (i.e. the assimilation rate of species). These 3 species were chosen as representative of 3 different trophic guilds based on literature data: $H$. mediterraneus actively forages on natatory benthopelagic prey (Pais 2002, Madurell \& Cartes 2005), H. italicus consumes mainly suprabenthic resources and $N$. aequalis preys on infauna (i.e. polychaetes) (Macpherson 1979, Mauchline \& Gordon 1984, Madurell \& Cartes 2006). Temporal changes in food resources available for fish and the changes in trophic levels elucidated by SIA are important aspects of deep-sea trophic ecology scarcely considered in previous approaches. We gave particular emphasis to the possible influence of different environmental factors (e.g. primary production, temperature and/or 
salinity that represent water mass dynamics) and biological features (e.g. size, weight and density of species present) on the seasonal trends observed in fish diets. This aspect is particularly relevant in the context of the deep-sea environment, which is not completely stable (see above), and studies on the influence of environmental variables on different biological aspects of deep-sea species are almost non-existent.

Another important aspect of this study was to test for fixative-dependent shifts of $\delta^{13} \mathrm{C}$ and $\delta^{15} \mathrm{~N}$ in preserved material. Fish samples used in this study were fixed in formalin on board ship, so that subsequent exchange and leaching needed evaluation. Thus, a comparison was performed between frozen samples and samples preserved in formalin for different intervals 6 , 12 and $24 \mathrm{mo}$ ). This was also necessary because, among the increasing number of published studies of SIA on preserved materials, contradictions and variability are evident in results and interpretations (Bosley \& Wainright 1999, Kaehler \& Pakhomov 2001, Arrington \& Winemiller 2002, Edwards et al. 2002, Sarakinos et al. 2002, Feuchtmayr \& Grey 2003, Sweeting et al. 2004, Kelly et al. 2006). Reported differences in isotope ratios between preserved and control samples have also been highly variable (from negligible differences up to $2.5 \%$ difference). Moreover, effects of preservatives (especially formalin) on fish tissues have been studied to some extent in fresh and brackish water fishes (Arrington \& Winemiller 2002, Vander Zanden et al. 2003, Kelly et al. 2006, Syväranta et al. 2008) and cultured seabass Dicentrarchus labrax (Sweeting et al. 2004), but this aspect never has been considered before for deep-sea species with lower tissue turnover (slower growth) than shelf-living species.

\section{MATERIALS AND METHODS}

Study area and sampling. Samples of Hoplostethus mediterraneus, Hymenocephalus italicus and Nezumia aequalis were collected (Table 1) over a period of 10 mo, on 6 experimental survey cruises from August 2003 to June 2004, at approximately bimonthly time intervals, within the framework of project IDEA (Influence of oceanographic structure and dynamics on demersal populations in waters of the Balearic Islands, see Massutí et al. 2008 for details). Sampling was carried out in the Algerian Basin off the Archipelago of Cabrera $\left(38.8^{\circ}\right.$ to $39.0^{\circ} \mathrm{N}, 2.8^{\circ}$ to $\left.3.0^{\circ} \mathrm{E}\right)$ at depths ranging from 576 to $752 \mathrm{~m}$. Each survey comprised a single haul at each of 3 depths (ca. 580, ca. 660 and ca. 750 m; see also Fanelli \& Cartes 2008). All hauls were carried out with a commercial otter trawling vessel. The horizontal opening of the gear, on average, was ca. $25.5 \mathrm{~m}$ $(\mathrm{SD}=1.76 \mathrm{~m})$ and the vertical opening was ca. $2.2 \mathrm{~m}$. Cod-end mesh size was $40 \mathrm{~mm}$. Haul duration was about $1 \mathrm{~h}$. Abundance (ind. $\mathrm{km}^{-2}$ ) and biomass $\left(\mathrm{g} \mathrm{km}^{-2}\right)$ were calculated after standardising catches to the swept area. Distance and trawl mouth width were recorded using a SCANMAR system attached to the trawl for each haul.

Immediately after capture, specimens were fixed in $10 \%$ buffered formalin. Once in the laboratory, fish were measured to the nearest $1 \mathrm{~mm}$ (total length [TL] for Hoplostethus mediterraneus and pre-anal length [PAL] for the two macrourids, corresponding to $26.4 \%$ of TL in Hymenocephalus italicus and to $26 \%$ of TL in Nezumia aequalis, according to the information available in fishbase, www.fishbase.org), weighed to the nearest $0.1 \mathrm{~g}$ and dissected for stomach content analysis. A sample of dorsal white muscle was taken from some specimens for stable isotope analysis.

Stomach contents analysis and data processing. Prey items were identified to the lowest possible taxonomic level, counted under a binocular microscope and weighed (precision, $0.0001 \mathrm{~g}$ ) after excess moisture had been removed by blotting with tissue paper. The contribution of each prey item in the fishes' diet was estimated using the percentage frequency of occurrence $(\% \mathrm{~F})$, the percentage of numerical abundance $(\% \mathrm{~N})$, the percentage of gravimetric composition $(\% \mathrm{~W})$ and index of relative importance $(\mathrm{IRI})=(\% \mathrm{~N}$ $+\% \mathrm{~W}) \times \% \mathrm{~F}_{\text {, }}$ expressed as percent IRI $(\% \mathrm{IRI})=$ $($ IRI $/ \Sigma$ IRI $) \times 100$. Prey items were sorted in decreasing order according to their \%IRI contribution, and then cumulative \%IRI was calculated (see Hyslop 1980 for a review). Stomach fullness (stomach weight/fish weight $\times 100$ ) and trophic diversity (Shannon-Wiener diversity index $H^{\prime}$ ) indices were also calculated. Diet was characterised for each species by month.

Table 1. Hoplostethus mediterraneus, Hymenocephalus italicus and Nezumia aequalis. Number of specimens dissected (number of fishes with food in stomachs in brackets) by month and year. Length ranges (total length for $H$. mediterraneus and PAL for $H$. italicus and N. aequalis) are also included

\begin{tabular}{|c|c|c|c|c|c|c|c|}
\hline \multirow{2}{*}{ Species } & \multicolumn{3}{|c|}{2003} & \multicolumn{3}{|c|}{2004} & \multirow{2}{*}{$\begin{array}{l}\text { Length range } \\
(\mathrm{mm})\end{array}$} \\
\hline & August & September & November & February & April & June & \\
\hline H. mediterraneus & $59(37)$ & $53(33)$ & $44(29)$ & $34(22)$ & $15(8)$ & $39(22)$ & $67-214$ \\
\hline H. italicus & $41(30)$ & $31(22)$ & $60(41)$ & $36(24)$ & $27(23)$ & 32 (25) & $25-43$ \\
\hline N. aequalis & $45(34)$ & $21(18)$ & $56(34)$ & $69(46)$ & $28(22)$ & $39(31)$ & $23-52$ \\
\hline
\end{tabular}


To measure sample size sufficiency (i.e. the number of stomachs to be examined), the cumulative $H^{\prime}$ was plotted against the cumulative number of randomly pooled analysed stomachs (Ferry \& Cailliet 1996) for each species. We repeated this procedure 5 times using a progressively smaller number of stomachs $(100,95,85,75$ and $50 \%$ of sample size). We calculated logistic and linear regressions each time and compared the goodness of fit coefficient $\mathrm{R}^{2}$ calculated for a logistic curve with the one calculated for the linear relation. The sample size was considered sufficient when $\mathrm{R}^{2}$ from the logistic curve was higher than $\mathrm{R}^{2}$ from the linear regression. This was the case for all three species during the 6 mo (for macrourids a mean sample number of 15 stomachs per month was considered adequate, while for Hoplostethus mediterraneus it was 20) except for $H$. mediterraneus from February to June for which few individuals (only 15 individuals in April, 8 with full stomachs) were collected in this period due to the abundance pattern of this species in the area (Moranta et al. 2008). With 15 stomachs the $\mathrm{R}^{2}$ value for the linear relation in Hymenocephalus italicus was 0.98, while for the logistic curve it was 0.99 ; for Nezumia aequalis the $\mathrm{R}^{2}$ from the logistic curve $\left(\mathrm{R}^{2}\right.$ log $)$ was higher than that from the linear regression $\left(\mathrm{R}^{2}\right.$ lin $)$ using 12 stomachs $\left(R^{2}{ }_{l o g}=0.99\right.$ versus $R^{2}$ lin $\left.=0.97\right)$, while for $H$. mediterraneus at least 20 stomachs were necessary (with 20 stomachs, $\mathrm{R}_{\text {log }}^{2}=0.98$ versus $\mathrm{R}_{\text {lin }}^{2}=0.93$ ).

Dietary analyses were performed with non-parametric univariate and multivariate techniques. First, we tested whether the rationale for choosing the 3 species, based on literature data, was consistent with our own results. Thus, separations among the diets of the species were visualised by principal coordinates analysis (PCA), based on the Bray-Curtis resemblance matrix of 4th-root transformed, aggregated weight data. The significance of separation among the 3 species' diets was tested by a 1-way analysis of similarities (ANOSIM) (Clarke \& Warwick 1995). The most typifying food species for each fish was determined by SIMPER procedure (Clarke 1993) and appears as a vector overlay on the PCA plot.

Second, we analysed temporal changes in the diet of each species. Permutational multivariate analysis of variance (PERMANOVA) (Anderson et al. 2008) was used to analyse the multivariate data set for the complete experimental design. This method allows multivariate data to be analysed on the basis of any distance or dissimilarity measure of choice, with p-values obtained using permutations. In the case of Hoplostethus mediterraneus the experimental design had one factor, month (fixed with 6 levels, corresponding to the 6 mo when sampling was carried out). For the 2 macrourids the experimental design had 2 factors (month with 6 levels and depth, nested in month, with
3 levels). PERMANOVA was based on modified Gower distance after a 4th-root transformation of the multivariate set of data. This measure of resemblance was deemed the most suitable for stomach content data, which are generally skewed and contain many zeros (Anderson et al. 2008, Fanelli \& Cartes 2008). The 4throot transformation has been considered the most appropriate for weight data (Clarke \& Warwick 1995, Anderson et al. 2008); it reduces the contribution of highly abundant species in relation to less abundant ones. Significance was set at $p=0.05$ and $p$-values were obtained using 9999 permutations of residuals under restricted permutations of the raw data. That is the recommended method when there is only a single factor (e.g. for H. mediterraneus) and under the reduced model when there are 2 factors (Anderson et al. 2008), as in the case of the macrourids. A SIMPER analysis was applied to each species to determine the most typifying prey species for month and depth, when those variables were found to be significant.

Stable isotope analysis. Sample preparation: From 3 specimens of each species from each month, a portion of white muscle close to the dorsal fin was dissected and prepared for stable isotope analysis. For each species we chose 3 specimens of the same size throughout the sampling period (Hoplostethus mediterraneus: mean TL $=164.9 \pm 12.1 \mathrm{~mm}$, ANOVA $F_{1,12}=1.81, \mathrm{p}>$ 0.05; Hymenocephalus italicus: mean PAL $=35.4 \pm 2.5$ $\mathrm{mm}, F_{1,12}=1.48, \mathrm{p}>0.05$; Nezumia aequalis: mean $\left.\mathrm{PAL}=44.0 \pm 1.0 \mathrm{~mm}, F_{1,12}=0.33, \mathrm{p}>0.05\right)$ to ensure that observed changes in stable isotope signatures were due to a temporal effect (month/season) and not to size differences. Three replicates (with no significant differences in the size of analyzed specimens) are widely accepted and used in isotope-based trophic web studies. However, to add power to our analysis and reduce Type II error, we randomly analyzed supplementary samples for $N$. aequalis (IDEA0803; $\mathrm{n}=3$ ) and $H$. italicus (IDEA0204; $\mathrm{n}=3$ ). We performed a power analysis to calculate the minimum sample size required to accept the outcome of the statistical twotailed $t$-test with a particular level of confidence (power). The power of a statistical test is the probability that the test will reject a false null hypothesis (i.e. that it will not make a Type II error). As power increases, the chances of a Type II error decrease. The probability of a Type II error is referred to as the false negative rate $(\beta)$. Therefore, power is equal to $1-\beta$. Power analysis was performed by using the software Statistica 6.0. The results confirmed that 3 replicates are enough in our case (critical $t=1.98$, actual power $=$ $0.81, \alpha=0.05, \beta=0.8$ ).

Samples were dried to constant weight at $60^{\circ} \mathrm{C}$, then ground to a fine powder. Using continuous flow, the samples were introduced into a Finnigan Delta XP plus 
isotope-ratio mass spectrometer for isotopic analysis (CNR-IAMC, Naples). Three capsules of an international standard (urea) were analysed at the beginning of each sequence, plus 1 capsule every 6 samples to compensate for machine drift and for quality control. Experimental precision (based on the SD of replicates of the internal standard) was $<0.2 \%$ for $\delta^{15} \mathrm{~N}$ and $<0.1 \%$ for $\delta^{13} \mathrm{C}$. The $\delta^{13} \mathrm{C}$ and $\delta^{15} \mathrm{~N}$ values were obtained in parts per thousand (\%o) relative to Vienna Pee Dee Belemnite (VPDB) and atmospheric $\mathrm{N}_{2}$ standards, respectively, according to the following formula: $\delta^{13} \mathrm{C}$ or $\delta^{15} \mathrm{~N}=\left[\left(\mathrm{R}_{\text {sample }} / \mathrm{R}_{\text {standard }}\right)-1\right] \times 10^{3}$, where $\mathrm{R}=$ ${ }^{13} \mathrm{C} /{ }^{12} \mathrm{C}$ or ${ }^{15} \mathrm{~N} /{ }^{14} \mathrm{~N}$.

Organic carbon and total nitrogen elemental composition were determined from the residues of $\mathrm{CO}_{2}$ and $\mathrm{N}_{2}$ gases. C:N ratios were measured simultaneously during stable isotope analysis from the percent element data.

Fixative dependent shifts of $\delta^{13} C$ and $\delta^{15} N$ in preserved fish samples: Since all samples during IDEA cruises were fixed in formalin, some specimens were collected in the Algerian Basin (i.e. in the area where IDEA cruises were carried out) in May 2005 within the BALAR-MEDITS survey (Massutí \& Reñones 2005) to assess for the fixative dependent shifts of $\delta^{13} \mathrm{C}$ and $\delta^{15} \mathrm{~N}$ in preserved fish samples compared with frozen samples. Portions of white muscle were dissected from the fish. From the same specimens (3 of each species Hoplostethus mediterraneus: mean TL $=155.1 \pm$ $7.2 \mathrm{~mm}$; Hymenocephalus italicus: mean PAL $=39.8 \pm$ $6.3 \mathrm{~mm}$; Nezumia aequalis: mean PAL $=48.8 \pm 5.1 \mathrm{~mm}$; ANOVA $\mathrm{p}>0.05$ for the 3 species) several tissue cubes were prepared, oven-dried and used as controls, while other tissue cubes were fixed in formalin and removed from the treatment after 6, 12 and 24 mo. They were then oven dried for SIA. Differences between the size of specimens used for the experiment and those used to assess for temporal differences were negligible and in any case not significant.

Data analysis: To assess the fixative-dependant shift of $\delta^{13} \mathrm{C}$ and $\delta^{15} \mathrm{~N}$ in preserved material, differences in the isotopic composition of unfixed samples (C) and samples for each period of formalin preservation (F1, F2 and F3, respectively, after 6, 12 and 24 mo) were tested by 1-way ANOVA, with time of preservation as a fixed factor. When results showed an effect of fixation on tissue samples, they were investigated by $a$ posteriori comparisons using Student-Neuman-Keuls (SNK) test (Underwood 1997).

If the results of the experiment were negative (no effect of fixation on tissue samples after different time intervals), temporal variations in trophic levels $\left(\delta^{15} \mathrm{~N}\right)$ and sources of carbon $\left(\delta^{13} \mathrm{C}\right)$ of samples collected during IDEA cruises were tested by one-way ANOVA for each species, with month as a fixed factor. The $\delta^{13} \mathrm{C}$ values of samples collected during IDEA were also normalised for lipid concentration according to Post et al. (2007); thus, $\delta^{13} \mathrm{C}$ values of our untreated samples (not defatted) were converted to normalised $\delta^{13} \mathrm{C}$ values according to $\delta^{13} \mathrm{C}_{\text {normalised }}=\delta^{13} \mathrm{C}_{\text {untreated }}-3.32+0.99$ $\times \mathrm{C}: \mathrm{N}_{\text {sample }}$ C: $\mathrm{N}_{\text {sample }}$ was the $\mathrm{C}: \mathrm{N}$ ratio of samples collected during IDEA. Afterwards we analysed temporal trends for normalised samples and compared results with values before accounting for lipid content.

Since data on the isotopic signatures of dominant mesopelagic and suprabenthic fauna are available from the same area where fish were collected (Fanelli et al. 2009), and because diet-switch experiments confirm that the isotopic turnover of consumers frequently lags the isotopic turnover of their diets (Hesslein et al. 1993, Herzka \& Holt 2000, Harvey et al. 2002), we calculated the dietary $\delta^{15} \mathrm{~N}$ values of the 3 species expected from the isotopic values of their prey. Thus for each species, the nitrogen isotope signature predicted from its diet was calculated using a weightedaverage equation of the following form (Clarke et al. 2005):

$$
\sum_{i=1}^{K} \delta^{15} N \frac{b_{i}}{b_{t}}+f, \quad \text { where } b_{t}=\sum_{i=1}^{k} b_{i}
$$

and where $\delta^{15} \mathrm{~N}$ is the nitrogen isotope signature of the $i$ th prey item, $b_{i} / b_{t}$ is the proportion of diet biomass observed for that prey item, and $f$ is the trophic fractionation coefficient, which was taken as $2.54 \%$ for $\delta^{15} \mathrm{~N}$ (Vanderklift \& Ponsard 2003). We then compared the dietary $\delta^{15} \mathrm{~N}$ values with the values resulting from the direct analysis of fish tissues. Finally, we estimated the goodness of fit between the dietary and fish tissue values, delayed by 1, 2 or more months, by calculating the $\mathrm{R}^{2}$ of the correlations between dietary and observed values.

It was only possible to collect a limited number of Hoplostethus mediterraneus from February to June, due to the behavioral dynamics of this species (Moranta et al. 2008), which probably includes a period of aggregation and dispersion, as earlier observed for $H$. atlanticus (Rosecchi et al. 1988). For this reason we calculated the range of all possible food sources of $H$. mediterraneus by a mixing models computation to integrate the results obtained by stomach contents analysis. For this estimation we used IsoSource, a Visual Basic program created to perform these procedures and described in Philips \& Gregg (2003). This model was chosen among many others (e.g. MixSIR, STEP and SOURCE, SIAR) because it is quite easy to use, available free of charge and complete. Many of the assumptions of IsoSource are implicit in other highly spread mixing models such as STEP and SOURCE (Lubetkin \& Simenstad 2004). IsoSource employs a mass balance approach to esti- 
mate the range of all possible diet proportions from 0 to $100 \%$ for as many as 10 contributing prey sources. The model outputs all isotopic combinations that sum to the isotopic signature of the consumer as viable solutions (Phillips \& Gregg 2003). Briefly, the user supplies the isotopic signatures of the sources (the prey) and the mixture (in our case the predator, $H$. mediterraneus), along with the desired source increment $(1 \%)$ and the mass balance tolerance $(0.1 \%)$. Output files include all the feasible source combinations, with histograms and descriptive statistics on the distributions for each source. Isotopic signatures of the sources (prey) include the isotopic values of the dominant species in the diet throughout the whole sampling period (data of prey species used in mixing models are presented in Table 2). Mixing polygons created around the adjusted consumer on a $\delta^{13} \mathrm{C}$ and $\delta^{15} \mathrm{~N}$ scatter plot indicate possible source contributions. IsoSource uses the location and distance of sources around the adjusted consumer on a $\delta^{13} \mathrm{C}$ and $\delta^{15} \mathrm{~N}$ scatterplot to estimate possible diet contributions (Phillips \& Gregg 2003). A 'constrained solution' occurs when the consumer isotopic signature is nearest the line connecting 2 sources. Those 2 sources contribute the greatest to that consumer's diet, which is indicated by a more complete bell-shaped curve of possible solutions. A consumer signature located more toward the middle of the polygon is considered 'diffuse,' where multiple sources contribute comparably to the organism's diet, often indicated by incomplete curves illustrating a more intermittent diet contribution. We expressed the range of possible solutions in histogram form with bell-shaped curves representative of sources contributing the most to the diet of a consumer.

We also considered a 'per-step' trophic fractionation between fish and their prey of $2.54 \%$ according to Vanderklift \& Ponsard (2003). Output files include all the feasible source combinations, with histograms and descriptive statistics on the distributions for each source.

Table 2. Hoplostethus mediterraneus. Mean $\pm \mathrm{SD} \delta^{15} \mathrm{~N}$ and $\delta^{13} \mathrm{C}$ values of the prey used for the computation of mixing models for $H$. mediterraneus, number of replicates (n) per species/taxon is also given. Amp: Amphipoda; Iso: Isopoda; Mys: Mysidacea; Dec: Decapoda

\begin{tabular}{|llccr|}
\hline Taxon & Prey & $\delta^{15} \mathrm{~N}(\%)$ & $\delta^{13} \mathrm{C}(\%)$ & $\mathrm{n}$ \\
\hline Amp & Tryphosites longipes & $5.76 \pm 0.84$ & $-20.04 \pm 0.9$ & 20 \\
Iso & Natatolana borealis & $8.10 \pm 1.18$ & $-19.8 \pm 2.1$ & 16 \\
Mys & Boreomysis arctica & $6.33 \pm 0.27$ & $-19.81 \pm 0.7$ & 16 \\
Dec & Pasiphaea spp. & $7.45 \pm 0.23$ & $-19.97 \pm 0.13$ & 4 \\
Dec & Sergestidae & $5.56 \pm 0.75$ & $-20.36 \pm 0.07$ & 16 \\
Dec & Plesionika martia & $7.35 \pm 0.67$ & $-19.28 \pm 0.87$ & 20 \\
Fish & Myctophidae & $7.80 \pm 0.27$ & $-19.03 \pm 0.68$ & 27 \\
\hline
\end{tabular}

Trophic level estimates: Trophic levels were calculated with $\delta^{15} \mathrm{~N}$ data from fish using different species as references: the hyperiid amphipod Vibilia armata (mean $( \pm \mathrm{SD}) \delta^{15} \mathrm{~N}=3.36 \pm 0.14 \%$, Fanelli et al. 2009) for Hoplostethus mediterraneus and 2 selective surface deposit feeders, the cumaceans Cyclaspis longicaudata and Plathysymphus typicus (mean $( \pm \mathrm{SD}) \delta^{15} \mathrm{~N}=$ $2.26 \pm 0.89 \%$, Fanelli et al. 2009), for the 2 macrourid fishes. The rationale behind these choices was that $H$. mediterraneus has strongly pelagic habits and is more linked to the pelagic food web, while macrourids are connected to the detritus-based food web. Thus, deposit feeders are better suited as reference material for macrourids than filter feeders.

The $\delta^{15} \mathrm{~N}$ values were converted to trophic levels based on the assumption that there was a fractionation of $2.54 \%$ per trophic level (Vanderklift \& Ponsard 2003) and that primary consumers have a trophic level of 2 :

$$
\text { Trophic Level }=\left(\frac{\delta^{15} \mathrm{~N}_{\text {Fish }}-\delta^{15} \mathrm{~N}_{\mathrm{PC}}}{2.54}\right)
$$

where $\delta^{15} \mathrm{~N}_{\text {Fish }}$ is the mean $\delta^{15} \mathrm{~N}$ of that species and $\delta^{15} \mathrm{~N}_{\mathrm{PC}}$ is the mean $\delta^{15} \mathrm{~N}$ of primary consumers (filter feeders and deposit feeders). Since different investigators have dissimilar opinions about the $2.54 \%$ fractionation point, we decided to also calculate the trophic level by using the value of per-step trophic fractionation of $3.25 \%$, reported by Vanderklift \& Ponsard (2003) for carnivorous vertebrates, and compare the trophic levels obtained with the 2 values. We chose the values reported in Vanderklift \& Ponsard (2003) because they were generated by a meta-analysis of 134 estimates of fractionation $(\Delta)$ from 32 peerreviewed papers including 14 estimates for fish $(9$ publications).

Correlation with abiotic and biotic factors. To check for possible correlations between fullness and the sampling characteristics (depth and month), the environmental variables (salinity and temperature on the bottom and $5 \mathrm{~m}$ above the bottom, grain size [mean and mode], chlorophyll a [chl a] recorded at different time intervals before and simultaneously with sampling) and the biological features of the fish species (TL or PAL, weight and density of the species in the environment), a Spearman's rank correlation was performed for each species separately (see also Fanelli \& Cartes 2008). All of the above variables were tested as possible factors that influence feeding (fullness). Spearman's rank correlation is a non-parametric measure that can test the direction and strength of the relationship between 2 variables; thus, when correlations are significant, the sign of the correlation (positive or negative) can give a useful indication of the ecological relationship.

All the statistical analyses were performed with PRIMER 6 and PERMANOVA+ (Clarke \& Warwick 
1995, Anderson et al. 2008) and STATISTICA 6.0. Mixing models were computed with IsoSource (available at www.epa.gov/wed/pages/models.htm).

\section{RESULTS}

\section{Preserved versus frozen samples}

No significant differences (ANOVA, p > 0.05 for all 3 species) were observed in $\delta^{15} \mathrm{~N}$ values between controls (frozen) and preserved samples after 6, 12 or 24 mo (Table 3a). The duration of preservation (from 6 to $24 \mathrm{mo}$ ) did affect carbon isotopic ratios of muscle in all the analyzed species, but in different ways (Table $3 b$ ). In all 3 species, $\delta^{13} \mathrm{C}$ values were depleted with respect to frozen samples after 24 mo. For the macrourids there was a slight enrichment after 6 mo of preservation, while in Hoplostethus mediterraneus depletion increased with time of preservation, reaching ca. $2 \%$ after 24 mo. Depletion after 24 mo was ca. $2 \%$ in Hymenocephalus italicus and $0.8 \%$ in Nezumia aequalis. Thus, temporal variations in $\delta^{13} \mathrm{C}$ must be interpreted with caution because there are fixativedependent shifts. There are previously published studies, when $\delta^{13} \mathrm{C}$ shifts are ca. $2 \%$ or lower, in which $\delta^{13} \mathrm{C}$ values from formaldehyde-preserved specimens have been used to elucidate food web structure. No significant differences were detected between the $\mathrm{C}: \mathrm{N}$ ratios of frozen and preserved samples.

\section{Overall species analysis}

PCA analysis showed a well-defined segregation among diets of the 3 species (Fig. 1), as expected. The first axis, which explains $34.5 \%$ of the total variation, separates the macrourids, Nezumia aequalis and Hymenocephalus italicus, from Hoplostethus mediterraneus. The second axis, explaining $20.3 \%$ of the total variation, is probably linked to depth, separating $H$.

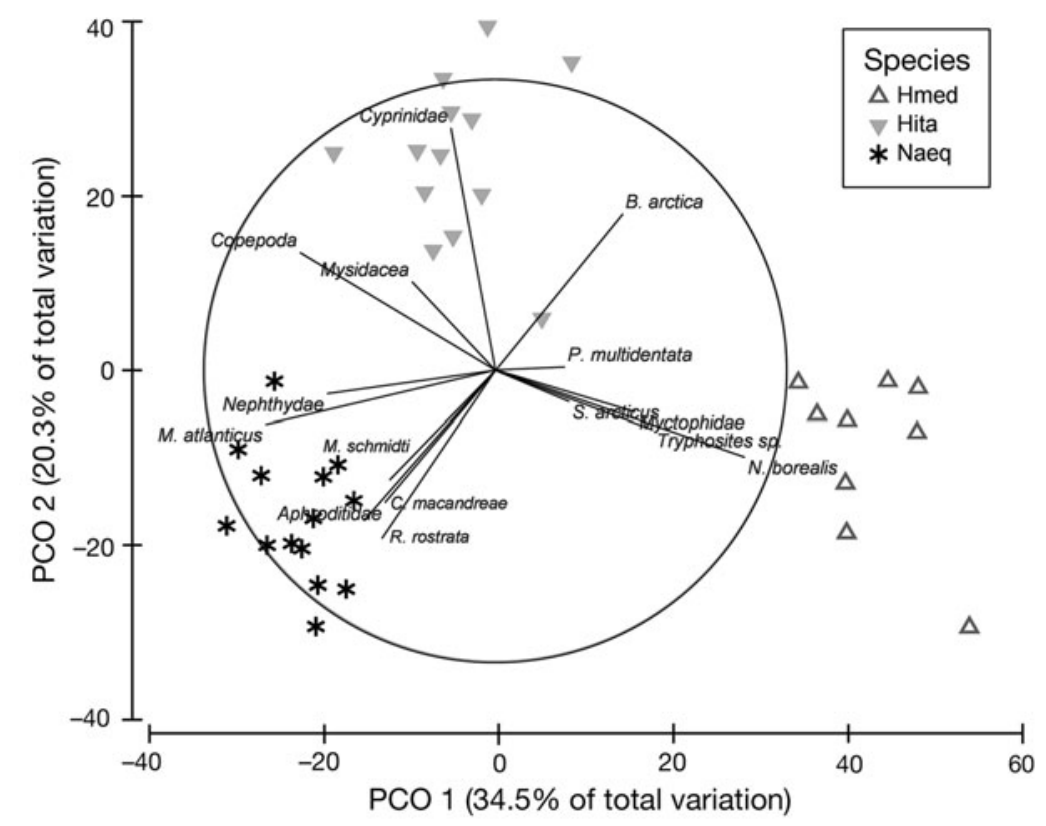

Fig. 1. Hoplostethus mediterraneus, Hymenocephalus italicus and Nezumia aequalis. Principal coordinates analysis of stomach contents samples of $H$. mediterraneus (Hmed), H. italicus (Hita) and N. aequalis (Naeq), based on the Bray-Curtis resemblance matrix of 4th-root transformed weight data; vectors indicate the species that contributed most to similarity with each species and/or to dissimilarity among species, based on SIMPER results. PCO: principal coordinate

Table 3. Hoplostethus mediterraneus, Hymenocephalus italicus and Nezumia aequalis. (a) Mean $\pm \mathrm{SD} \delta^{15} \mathrm{~N}$ and $\delta^{13} \mathrm{C}$ values of control (C) and preserved samples removed from fixative after 6 (F1), 12 (F2) and 24 (F3) mo. (b) ANOVA results for $\delta^{13} \mathrm{C}$ values between C samples and F1, F2 and F3. Results of post hoc Student-Neuman-Keuls tests (SNK) are also reported for each species. ${ }^{* *} \mathrm{p}<0.01,{ }^{* * *} \mathrm{p}<0.001$

\begin{tabular}{|c|c|c|c|c|c|c|c|}
\hline \multirow{2}{*}{$\begin{array}{l}\text { (a) } \\
\text { Sample }\end{array}$} & \multicolumn{3}{|c|}{ H. mediterraneus } & \multicolumn{2}{|c|}{ H. italicus } & \multicolumn{2}{|c|}{ N. aequalis } \\
\hline & $\delta^{15} \mathrm{~N}$ & \multicolumn{2}{|c|}{$\delta^{13} \mathrm{C}$} & \multicolumn{2}{|c|}{$\delta^{15} \mathrm{~N} \quad \delta^{13} \mathrm{C}$} & \multicolumn{2}{|c|}{$\delta^{15} \mathrm{~N} \quad \delta^{13} \mathrm{C}$} \\
\hline $\mathrm{C}$ & $11.29 \pm 0.09$ & -17.1 & 0.05 & $9.20 \pm 0.07$ & $-17.62 \pm 0.31$ & $11.09 \pm 0.58$ & $-16.98 \pm 0.21$ \\
\hline F1 & $11.45 \pm 0.05$ & -17.2 & 0.18 & $9.15 \pm 0.14$ & $-16.62 \pm 0.26$ & $11.18 \pm 0.21$ & $-16.20 \pm 0.08$ \\
\hline F2 & $10.75 \pm 0.26$ & -17.8 & 0.22 & $8.98 \pm 0.43$ & $-17.52 \pm 0.11$ & $11.03 \pm 0.98$ & $-17.13 \pm 0.14$ \\
\hline F3 & $11.45 \pm 0.09$ & -19.2 & 0.04 & $9.55 \pm 0.26$ & $-19.54 \pm 0.14$ & $11.40 \pm 0.33$ & $-17.86 \pm 0.08$ \\
\hline (b) & \multirow[b]{2}{*}{$\mathrm{df}$} & \multicolumn{2}{|c|}{ H. mediterraneus } & \multicolumn{2}{|c|}{ H. italicus } & \multicolumn{2}{|c|}{ N. aequalis } \\
\hline Source & & MS & $F$ & MS & $F$ & MS & $F$ \\
\hline$\delta^{13} \mathrm{C}$ & 3 & 4.18 & $17.35^{* * *}$ & 3.52 & $8.29^{* *}$ & 2.08 & $107.0^{* * *}$ \\
\hline Error & 8 & 0.24 & & 0.42 & & 0.02 & \\
\hline SNK & & F3 $<F$ & $\mathrm{~F} 1=\mathrm{C}$ & F3 $<F$ & $2=\mathrm{F} 1=\mathrm{C}$ & F3 $<$ F2 & $<\mathrm{C}<\mathrm{F} 1$ \\
\hline
\end{tabular}


mediterraneus and $N$. aequalis from $H$. italicus. The former species have their distributional centres of gravity (COG) deeper (normally at $700 \mathrm{~m}$ ) than $\mathrm{H}$. italicus. The ANOSIM routine provided evidence of a significant separation (global $\mathrm{R}=0.80, \mathrm{p}<0.001$ ) among the diets of the 3 species. Differences were greater between $H$. mediterraneus and $N$. aequalis (pairwise comparison, $\mathrm{R}=0.95, \mathrm{p}<0.001)$, than between the 2 macrourids $(\mathrm{R}=0.69, \mathrm{p}<0.001)$. As shown by SIMPER analysis, Natatolana borealis was the most typifying species in the H. mediterraneus diet (mean percentage contribution $=51.9 \%$ ), while the diet of $H$. italicus was dominated by mysids $(40.9 \%)$, copepods $(10.4 \%)$ and gammarids $(8.8 \%)$ (See also Fig. 1). Amphipods $(17.9 \%)$, isopods $(8.7 \%)$ and mysids $(20.3 \%)$ typified the diet of $N$. aequalis (see also Fig. 1). Benthic species such as polychaetes (including Nephthydae, Aphroditidae and some unidentified species) were also important, contributing more than $13 \%$ to the diet of $N$. aequalis. There was a gradient in the average dissimilarity among the species, in accordance with their feeding behaviours; dissimilarity was high between $H$. mediterraneus and $N$. aequalis $(80.1 \%)$, but less between $H$. mediterraneus and $H$. italicus $(73.8 \%)$ and still less between the 2 macrourids (64.2\%).

\section{Temporal variations in food sources}

\section{Hoplosthetus mediterraneus}

A total of 244 individuals of Hoplostethus mediterraneus were examined; among these $24(9.8 \%)$ were everted and $68(27.9 \%)$ were empty. A total of 152 stomachs were analysed for diet composition and contained 32 identified prey items (Table S1 in the supplement at www.int-res.com/articles/suppl/m402p213_ app.pdf). The diet consisted mainly of crustaceans and fish. Isopods (Natatolana borealis) were the dominant prey throughout the whole period studied, and ranged in size from 6.3 to $21.1 \mathrm{~mm}$ TL. They occurred in large numbers, up to 32 specimens in a single stomach. However, significant variations in their proportions (in term of \%IRI) were observed among seasons (Table S1): $N$. borealis was the most abundant prey from August to November (\%IRI values ranged from 97.5 to 98.8 ) and in June (\%IRI = 85.5). In February and April, $N$. borealis was replaced by Tryphosites spp. $(\%$ IRI $=51.2)$, Boreomysis arctica $(\%$ IRI $=24)$ and mesopelagic fish (\%IRI = 11 in April).

The lowest values of diversity $\left(H^{\prime}\right)$ were found in September and November due to the nearly complete dominance of Natatolana borealis in the diet (Table S1). A significant decrease in the mean number of prey ingested (ANOVA, $F_{5,151}=3.09, \mathrm{p}=0.01$ ) was observed in spring, whereas higher values were found in late summer (August/September). No significant differences were found in mean prey weight or stomach fullness (ANOVA, $\mathrm{p}>0.05$ ) by month.

PERMANOVA (1 factor: month, with 6 levels) provided evidence for statistical differences in diet as function of month $\left(F_{5,151}=2.19, \mathrm{p}<0.01\right)$, and the pairwise comparison located the source of variation between November and February (Table 4a). SIMPER analysis showed that the most typifying species was Natatolana borealis throughout the sampling period, its contribution to the similarity between pairs of samples per month ranged between $91.6 \%$ in August to $98.9 \%$ in November. The species that most contributed to similarity in February and April were Tryphosites spp. (43.4\% in February and $90.3 \%$ in April) and Boreomysis arctica (18.9\% in February and $9.7 \%$ in April). In June, $N$. borealis contributed $84.2 \%$ to the diet, with Tryphosites spp. and gammarids as secondary typifying species (5.3\% and $4.7 \%$, respectively). The highest values of similarity between paired samples were observed from August to November (more than 50\%).

\section{Hymenocephalus italicus}

A total of 227 Hymenocephalus italicus individuals were analysed, among which $14(6 \%)$ had the stomachs everted and 48 (21\%) were empty. From 165 stomachs containing food, 52 categories of prey items were identified (Table S2 in the supplement at www. int-res.com/articles/suppl/m402p213_app.pdf). Mysids dominated the diet of $H$. italicus all through the year, being most abundant in August (\%IRI = 84.7), November and June (both \%IRI $=77.7$ ) but still the most ingested prey during the other months (\%IRI ranged between 57 and 69). Other important prey items were copepods $(\% \mathrm{IRI}=14.2)$, isopods $(\% \mathrm{IRI}=11.1)$, ostra-

Table 4. Hoplostethus mediterraneus, Hymenocephalus italicus and Nezumia aequalis. PERMANOVA pairwise comparisons based on a Modified Gower resemblance matrix of 4th-root transformed biomass data of stomach contents under 9999 permutations of $H$. mediterraneus, $H$. italicus and $N$. aequalis (75 items). Values are $t$-values. ${ }^{*} p<0.05$; ${ }^{* *} \mathrm{p}<0.01$; ns: not significant

\begin{tabular}{|lccc|}
\hline Groups & H. mediterraneus & H. italicans & H. aequalis \\
\hline Aug, Sep & $1.03 \mathrm{~ns}$ & $1.09 \mathrm{~ns}$ & $0.77 \mathrm{~ns}$ \\
Sep, Nov & $0.56 \mathrm{~ns}$ & $1.06 \mathrm{~ns}$ & $0.86 \mathrm{~ns}$ \\
Nov, Feb & $2.45^{* *}$ & $1.57^{*}$ & $0.69 \mathrm{~ns}$ \\
Feb, Apr & $1.13 \mathrm{~ns}$ & $0.93 \mathrm{~ns}$ & $1.76^{* *}$ \\
Apr, Jun & $1.34 \mathrm{~ns}$ & $0.94 \mathrm{~ns}$ & $1.02 \mathrm{~ns}$ \\
Jun, Aug & $0.91 \mathrm{~ns}$ & $1.37^{*}$ & $1.18 \mathrm{~ns}$ \\
n & 32 & 52 & 75 \\
\hline
\end{tabular}


cods ( $\%$ IRI $=9.9)$ and amphipods $(\%$ IRI $=4.9)$, whereas polychaetes, fish and other crustaceans (e.g. cumaceans and decapods) were ingested only occasionally. At a species level, Boreomysis arctica, Natatolana borealis and Munnopsurus atlanticus were the main prey items in terms of \%IRI (Table S2). Trophic diversity values $\left(H^{\prime}, 2.42 \pm 0.18\right.$; see also Table S2) were approximately the same in all sampling periods. Mean prey weight varied significantly among months (Kruskal-Wallis test, $H=13.72, \mathrm{p}=0.02$ ), being higher in August and February, while number of prey and stomach fullness did not. Two-factor PERMANOVA provided evidence for significant differences among months $\left(F_{5,164}=1.53, \mathrm{p}<0.05\right)$ and depths $\left(F_{9,164}=1.49\right.$, $\mathrm{p}<0.01)$. At a temporal scale, major shifts occurred between November and February and between June and August (Table 4b). SIMPER analysis showed that a different contribution of benthopelagic prey to the diet was responsible for these separations (Table 5). In

Table 5. Hymenocephalus italicus. Percentage contributions of typifying species/ taxon (cut-off for low contribution at $80 \%$ ) to within-group similarity for the identified prey in stomach contents of $H$. italicus throughout the sampling period

\begin{tabular}{|c|c|c|c|c|}
\hline Prey species/taxon & $\begin{array}{c}\text { Average } \\
\text { abundance }\end{array}$ & $\begin{array}{l}\text { Average } \\
\text { similarity }\end{array}$ & $\begin{array}{c}\text { Contribution } \\
(\%)\end{array}$ & $\begin{array}{c}\text { Cumulative } \\
(\%)\end{array}$ \\
\hline \multicolumn{5}{|l|}{ August } \\
\hline \multicolumn{5}{|l|}{ Average similarity, 27.19} \\
\hline Boreomysis arctica & 1.86 & 19.48 & 71.62 & 71.62 \\
\hline Cyprinidae & 0.59 & 2.58 & 9.49 & 81.11 \\
\hline \multicolumn{5}{|l|}{ September } \\
\hline \multicolumn{5}{|l|}{ Average similarity, 22.76} \\
\hline Boreomysis arctica & 1.07 & 7.35 & 32.27 & 32.27 \\
\hline Cyprinidae & 1.09 & 6.32 & 27.78 & 60.06 \\
\hline Copepoda & 0.79 & 3.87 & 17 & 77.06 \\
\hline \multicolumn{5}{|l|}{ November } \\
\hline \multicolumn{5}{|l|}{ Average similarity, 22.94} \\
\hline Cyprinidae & 1.46 & 13.15 & 57.31 & 57.31 \\
\hline Boreomysis arctica & 1.03 & 5.48 & 23.88 & 81.2 \\
\hline \multicolumn{5}{|l|}{ February } \\
\hline \multicolumn{5}{|l|}{ Average similarity, 18.33} \\
\hline Boreomysis arctica & 1.41 & 11.96 & 65.23 & 65.23 \\
\hline Andaniexis mimonectes & $S \quad 0.52$ & 1.74 & 9.5 & 74.73 \\
\hline $\begin{array}{l}\text { Natatolana borealis } \\
\text { juvenile }\end{array}$ & 0.58 & 1.47 & 8.02 & 82.75 \\
\hline \multicolumn{5}{|l|}{ April } \\
\hline \multicolumn{5}{|l|}{ Average similarity, 24.89} \\
\hline $\begin{array}{l}\text { Natatolana borealis } \\
\text { juvenile }\end{array}$ & 1.11 & 7.01 & 28.17 & 28.17 \\
\hline Copepoda & 1 & 5.9 & 23.7 & 51.87 \\
\hline Mysidacea & 0.92 & 4.78 & 19.2 & 71.08 \\
\hline Boreomysis arctica & 1 & 4.42 & 17.74 & 88.82 \\
\hline \multicolumn{5}{|l|}{ June } \\
\hline \multicolumn{5}{|l|}{ Average similarity, 18.14} \\
\hline Mysidacea & 1.04 & 6.91 & 38.1 & 38.1 \\
\hline Cyprinidae & 0.8 & 3.98 & 21.97 & 60.07 \\
\hline Boreomysis arctica & 0.73 & 2.23 & 12.27 & 72.34 \\
\hline Copepoda & 0.59 & 2.05 & 11.3 & 83.64 \\
\hline
\end{tabular}

November, cyprinids contributed more than $57 \%$ to the diet of $H$. italicus, while in February $B$. arctica (65\%), Andaniexis mimonectes (10\%) and N. borealis $(8 \%)$ were the most typifying species. Mysids and cyprinids were the most important prey in June (accounting for more than 60\%), while in August $H$. italicus mostly preyed on $B$. arctica (70\%).

Depth was also an important factor associated with separation between samples: the contribution of Boreomysis arctica to the diet increased from $30.4 \%$ at $580 \mathrm{~m}$ to $63.1 \%$ at $750 \mathrm{~m}$, with a corresponding opposite trend in the consumption of other mysids $(18.6 \%$ at $580 \mathrm{~m}, 15.7 \%$ at $660 \mathrm{~m}$, and not a typifying taxon at $750 \mathrm{~m})$ and copepods $(14.3 \%$ at $580 \mathrm{~m}, 9.8 \%$ at $660 \mathrm{~m}$, and not typifying taxon at $750 \mathrm{~m}$ ).

\section{Nezumia aequalis}

A total of 258 Nezumia aequalis individuals were examined; however, 50 $(19.8 \%)$ stomachs were everted and 23 $(9.1 \%)$ were empty. A total of 185 stomachs were analyszed for diet composition and 75 prey items were identified (Table S3 in the supplement at www.intres.com/articles/suppl/m402p213_app. pdf). Gammarids were the most abundant prey in the diet of $N$. aequalis in August and September ( $\%$ IRI $=44.5$ and 36.5 , respectively), polychaetes were dominant in the diet from September to February (average \%IRI $=31.7$ ) and isopods were mainly ingested in April $(\%$ IRI $=40.7)$. Other crustaceans (e.g. cumaceans, decapods, tanaids and ostracods) were ingested less consistently (Table S3). At the species level, Munnupsurus atlanticus, Boreomysis arctica and Maera schmidti were the main prey items ingested in terms of \%IRI (Table S3). Ostracods occurred frequently in stomach contents, but their contribution in terms of weight was low (mean \%W $=2$ ); they are probably ingested accidentally. Trophic diversity was higher than in the other species examined $\left(H^{\prime}, 3.09 \pm 0.31\right)$.

Significant differences in mean weight of prey were found between February and April (post hoc Tukey's N HSD test, $\mathrm{p}<0.001)$. Mean fullness and mean number of prey in stomachs did not differ significantly (ANOVA, p $>0.05)$. 
PERMANOVA provided evidence for significant differences among samples as a function of month $\left(F_{5,184}\right.$ $=1.35, \mathrm{p}<0.05)$ and depth $\left(F_{9,184}=1.38, \mathrm{p}<0.001\right)$. The pairwise comparison performed on the factor Month showed 2 periods of dietary change, one between February and April and the other between June and August (Table 4c). Separation was mainly attributed to high consumption on benthopelagic resources (mysids and suprabenthic gammarids) in spring (April), contrasting with increasing predation on polychaetes from August (contribution to diet $23 \%$ ) to February (41\%) when, according to SIMPER analysis, polychaetes mostly typified the Nezumia aequalis diet (Table 6).

Depth appeared to be a strong factor separating samples; the major discontinuity in diet occurred between $580 \mathrm{~m}$ and 660 to $750 \mathrm{~m}$ of depth (PERMANOVA pairwise comparison, between 580 and $660 \mathrm{~m}: t=1.43, \mathrm{p}<0.01$; between 580 and $750 \mathrm{~m}: t=$ $1.29, \mathrm{p}<0.05$; between 660 and $750 \mathrm{~m}: t=1.07, \mathrm{p}>$

Table 6. Nezumia aequalis. Percentage contributions of typifying species/taxon (cut-off for low contribution at $50 \%$ ) to within-group similarity for the identified prey in stomach contents of $N$. aequalis throughout the sampling period

\begin{tabular}{|c|c|c|c|c|}
\hline Prey species/taxon & $\begin{array}{l}\text { Average } \\
\text { abundance }\end{array}$ & $\begin{array}{l}\text { Average } \\
\text { similarity }\end{array}$ & $\begin{array}{c}\text { Contribution } \\
(\%)\end{array}$ & $\begin{array}{c}\text { Cumulative } \\
(\%)\end{array}$ \\
\hline \multicolumn{5}{|l|}{ August } \\
\hline \multicolumn{5}{|l|}{ Average similarity, 21.00} \\
\hline Gammaridaea ind. & 0.91 & 3.33 & 15.87 & 15.87 \\
\hline Nepthydae & 0.92 & 2.93 & 13.98 & 29.84 \\
\hline Maera schmidti & 0.88 & 2.37 & 11.31 & 41.15 \\
\hline Ostracoda & 0.55 & 1.42 & 6.75 & 47.9 \\
\hline Rhachotropis spp. & 0.6 & 1.25 & 5.97 & 53.87 \\
\hline Polychaeta ind. & 0.62 & 1.24 & 5.92 & 59.79 \\
\hline \multicolumn{5}{|l|}{ September } \\
\hline \multicolumn{5}{|l|}{ Average similarity, 22.84} \\
\hline Nepthydae & 1.46 & 6.89 & 30.16 & 30.16 \\
\hline Gammaridaea ind. & 0.87 & 3.52 & 15.4 & 45.56 \\
\hline Boreomysis arctica & 0.88 & 2.77 & 12.14 & 57.69 \\
\hline \multicolumn{5}{|l|}{ November } \\
\hline \multicolumn{5}{|l|}{ Average similarity, 30.69} \\
\hline Munnupsurus atlanticus & $S \quad 1.26$ & 7.39 & 24.09 & 24.09 \\
\hline Nepthydae & 1.43 & 6.99 & 22.76 & 46.85 \\
\hline Gammaridaea ind. & 0.88 & 3.27 & 10.64 & 57.49 \\
\hline \multicolumn{5}{|l|}{ February } \\
\hline \multicolumn{5}{|l|}{ Average similarity, 22.45} \\
\hline Eunicidae & 1.16 & 4.39 & 19.57 & 19.57 \\
\hline Gammaridaea ind. & 0.99 & 4.36 & 19.44 & 39.02 \\
\hline Munnupsurus atlanticus & $S \quad 0.79$ & 3.11 & 13.84 & 52.86 \\
\hline Polychaeta ind. & 0.66 & 1.55 & 6.89 & 59.74 \\
\hline \multicolumn{5}{|l|}{ April } \\
\hline \multicolumn{5}{|c|}{ Average similarity, 29.08} \\
\hline Munnupsurus atlanticus & $S \quad 1.49$ & 9.6 & 33.02 & 33.02 \\
\hline Mysidacea ind. & 1.26 & 6.35 & 21.86 & 54.88 \\
\hline \multicolumn{5}{|l|}{ June } \\
\hline \multicolumn{5}{|c|}{ Average similarity, 27.35} \\
\hline Mysidacea ind. & 1.23 & 6.9 & 25.23 & 25.23 \\
\hline Munnupsurus atlanticus & $S \quad 1.09$ & 6.18 & 22.6 & 47.83 \\
\hline
\end{tabular}

0.05). The SIMPER routine showed that at $580 \mathrm{~m} \mathrm{Nezu-}$ mia aequalis preyed mainly on suprabenthic gammarids (e.g. Rhachotropis spp., Stegocephalidae), which contributed more than $24 \%$ to similarity, and mysids $(22.2 \%)$, whilst at 660 and $750 \mathrm{~m}$ depths polychaetes were the preferred prey items $(38 \%)$.

\section{Temporal variations in trophic position}

For Hoplostethus mediterraneus, the mean $( \pm \mathrm{SD})$ $\delta^{15} \mathrm{~N}$ value was $10.5 \pm 0.4 \%$; however, non-significant (ANOVA, $F_{5,12}=0.64, \mathrm{p}=0.68$ ) seasonal differences occurred, with the lowest value observed in September and the highest in April (Fig. 2a). The correlation between $\delta^{13} \mathrm{C}$ values of untreated (Fig. 2b) and normalised samples (Fig. 2c) was significant $(\mathrm{R}=0.86, \mathrm{p}=0.03$ ); 1 way ANOVA showed significant differences for $\delta^{13} \mathrm{C}$ values for normalised samples among months $\left(F_{5,12}=\right.$ $1.12, \mathrm{p}<0.05)$ but not for untreated samples $\left(F_{5,11}=3.06, \mathrm{p}=0.06\right)$.

The seasonal trend of dietary $\delta^{15} \mathrm{~N}$ values obtained by Eq. (1), based on isotopic composition of ingested prey, fit well with simultaneous values observed from fish tissues (= assimilated food) ( $r=0.73, p>0.05$; see also Fig. 3 ). Based on Eq. (2) the trophic position of Hoplostethus mediterraneus is 4.95 .

The results of IsoSource, for the periods when diet was well established based on stomach contents, are shown in Fig. 4a. To easily read the graphs some rules regarding graphical representation provided by Philips \& Gregg (2003) should be taken into account: (1) if the mixture is outside the convex polygon bounded by all sources, there is no possible solution to the linear mixing model; (2) mixtures near the periphery of the mixing polygon have well constrained solutions; (3) mixtures near the centre have more diffuse solutions and (4) narrow mixing polygons with small differences between sources have diffuse solutions. In summer the mixing polygon was narrow with the isotopic signature of Hoplostethus mediterraneus ('the mixture') falling in the middle (Fig. 4a, Summer). Myctophids (50th to 99th percentile: 31 to $44 \%$ ), Pasiphaeidae (50th to 99th percentile: 12 to $53 \%$, not shown in the graph) and Pandalidae (50th to 99th percentile: 14 to $60 \%$, not 


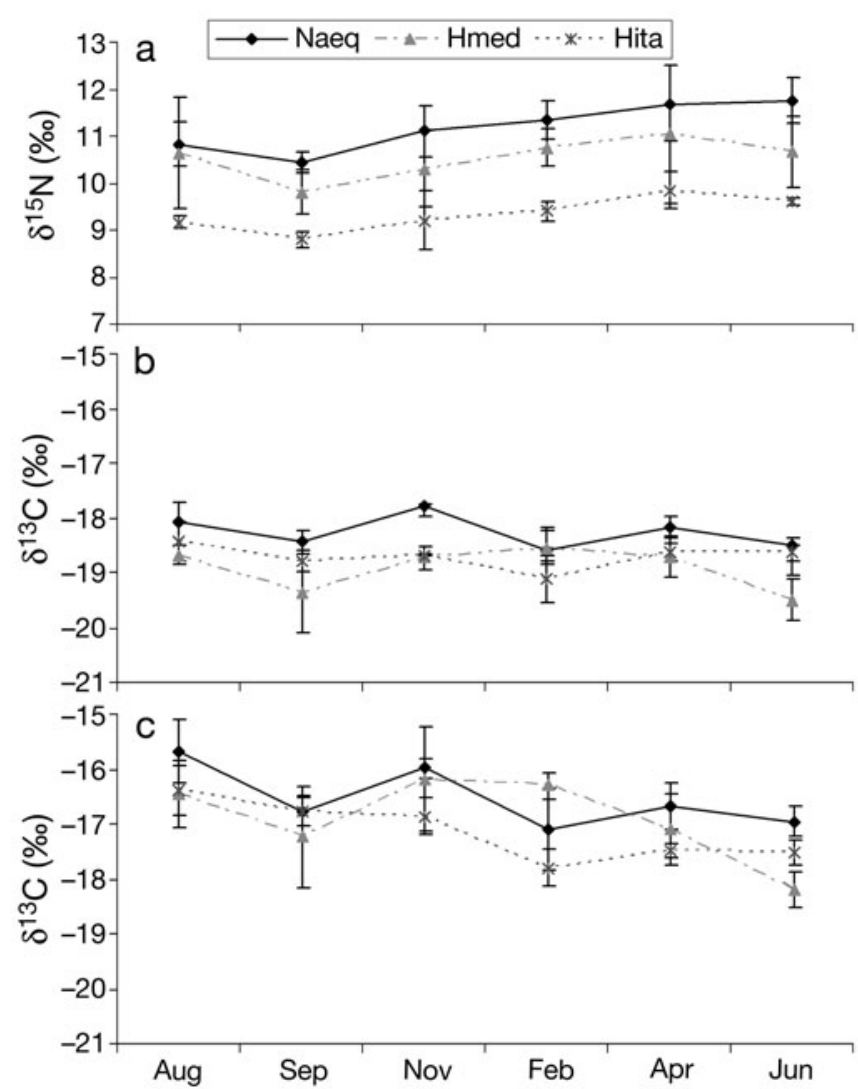

Fig. 2. Hoplostethus mediterraneus, Hymenocephalus italicus and Nezumia aequalis. Temporal variations of (a) $\delta^{15} \mathrm{~N}$, (b) $\delta^{13} \mathrm{C}$ and (c) normalised $\delta^{13} \mathrm{C}$ values by month of $H$. mediterraneus (Hmed), H. italicus (Hita) and $N$. aequalis (Naeq). Error bars indicate $\pm \mathrm{SD}$

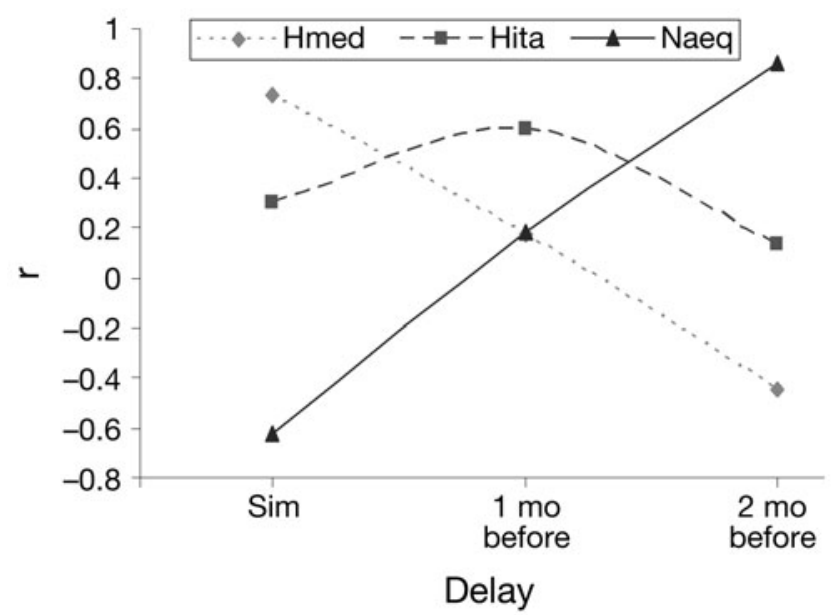

Fig. 3. Hoplostethus mediterraneus, Hymenocephalus italicus and Nezumia aequalis. Spearman's r correlations between expected (dietary) $\delta^{15} \mathrm{~N}$ values as calculated by Eq. (1) and observed values (Sim) as determined from direct tissue analysis for $H$. mediterraneus (Hmed), $H$. italicus (Hita) and $N$. aequalis (Naeq) and delayed by 1 (1 mo before) and 2 mo ( 2 mo before) shown in the graph) seemed to be more abundant prey than the preferred prey, Natatolana borealis, as indicated by stomach contents analysis (50th to 99th percentile: 7 to $25 \%$ ). In autumn the situation was similar (Fig. 4a, Autumn), although the mixing polygon was broad and the mixture fell close to the signatures of myctophids (50th to 99th percentile: 43 to $60 \%$ ) and $N$. borealis (50th to 99th percentile: 18 to $53 \%$ ), which represented the bulk of the diet, followed by Pasiphaeidae (50th to 99th percentile: 8 to $33 \%$ ), in good agreement with the results based on the diet and Eq. (1). The results of IsoSource, for the 2 seasons for which only a few stomachs were available, are shown in Fig. 4b. In winter the mixing polygon was broad with the mixture falling near one end, close to myctophid signatures (Fig. 4b, Winter). Fish appeared to constitute the majority of the diet (50th to 99th percentile: 40 to $63 \%$ ), with Sergestidae as an important secondary food source (50th to 99th percentile: 17 to $41 \%$ ), and the other potential food sources making up the remainder of the diet (Fig. 4b). In spring (Fig. 4b, Spring) fish again appeared to be important in the diet ( 26 to $54 \%$ ) together with $N$. borealis (4 to $26 \%$ ), while the other species (Tryphosites longipes, Boreomysis arctica, Pasiphaea spp. and Plesionika martia) had somewhat less precise, small to medium, dietary contributions (between 0 and $15 \%$ and 0 and $45 \%$; only T. longipes was reported in Fig. 4b).

Temporal changes occurred in $\delta^{15} \mathrm{~N}$ values of Hymenocephalus italicus (Fig. 2a) with the lowest value observed in September and the highest in April, although the differences were not significant. The correlation between $\delta^{13} \mathrm{C}$ values of untreated and normalised samples was not significant (Spearman's $r=0.67, p=0.19$ ); although a more depleted $\delta^{13} \mathrm{C}$ value occurred in February (Fig. 2b), $\delta^{13} \mathrm{C}$ values of untreated samples did not show significant differences by month, but the high variability among values (as showed by the wide confidence limits) may have influenced the test result. The $\delta^{13} \mathrm{C}$ values of normalised samples did differ significantly among months $\left(F_{5,12}=9.43, \mathrm{p}<0.001\right)$, with more depleted values evident from February to June compared with those from August to November.

For Hymenocephalus italicus, the highest correlation between dietary $\delta^{15} \mathrm{~N}$ and tissue values was obtained for tissue values from 1 mo before (Spearman's $\mathrm{r}=0.62$, $\mathrm{p}<0.05$; see also Fig. 3). Overall, the mean $\delta^{15} \mathrm{~N}$ value was $9.34 \pm 0.37 \%$, corresponding to a trophic level of 4.89, based on Eq. (2).

For Nezumia aequalis, $\delta^{15} \mathrm{~N}$ values showed only slight, non-significant differences, with the lowest value observed in September and the highest in June (Fig. 2a). The correlation between $\delta^{13} \mathrm{C}$ values of untreated and normalised samples was significant (Spearman's $\mathrm{r}=0.85, \mathrm{p}=0.03) ; \delta^{13} \mathrm{C}$ values of 

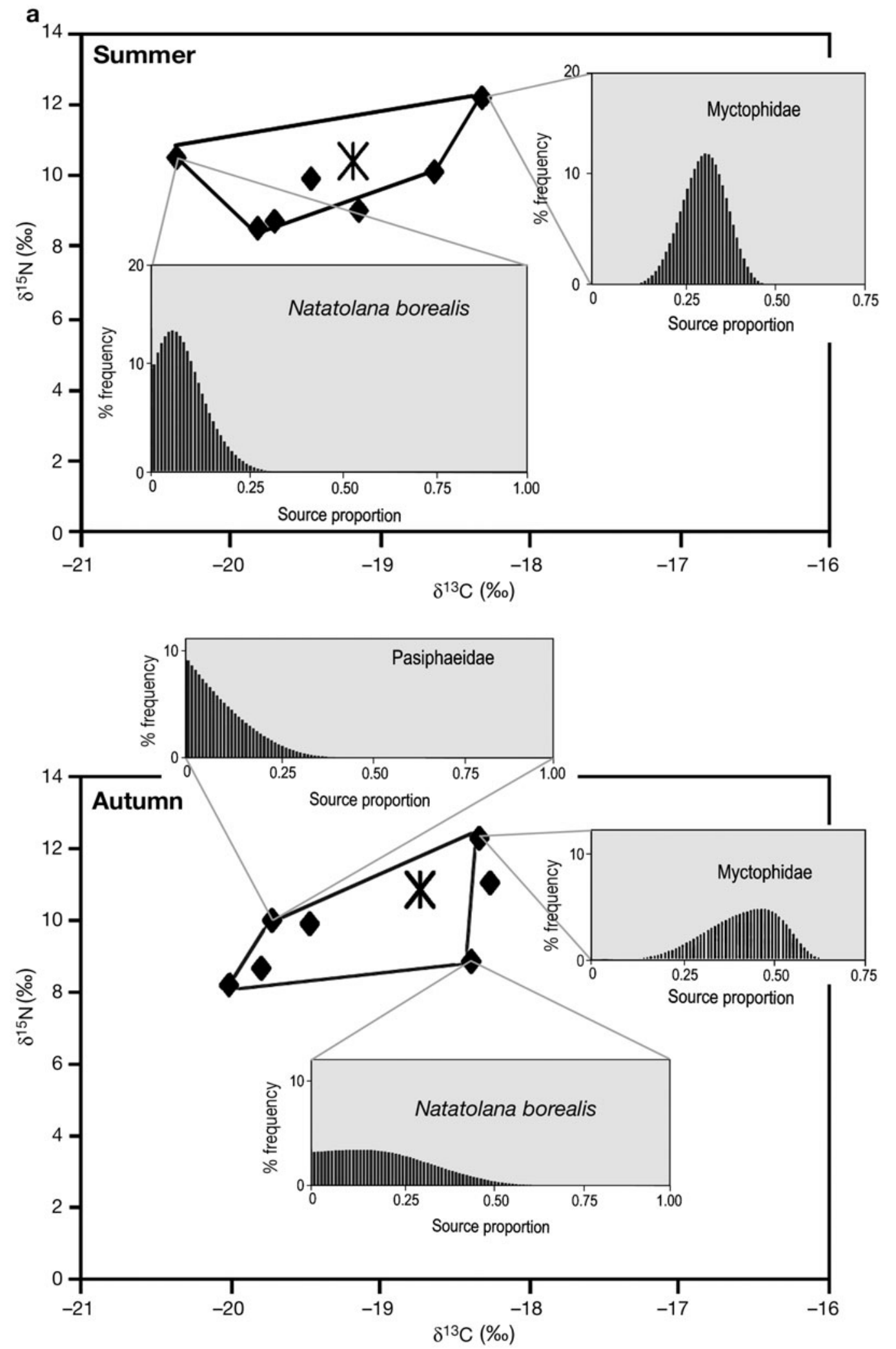

Fig. 4. Hoplostethus mediterraneus. Mixing polygon for $\delta^{13} \mathrm{C}$ and $\delta^{15} \mathrm{~N}$ signatures of 7 food sources for (a) periods for which diet was well established (summer and autumn) and (b) periods for which diet was not well established (winter and spring, few specimens) for $H$. mediterraneus (after correcting for trophic fractionation). Histograms show the distribution of feasible contributions from the 3 most important sources of $H$. mediterraneus diet (indicated by asterisk [ $\left.{ }^{*}\right]$ ). Values shown in the boxes are 1 to 99 percentile ranges for these distributions 

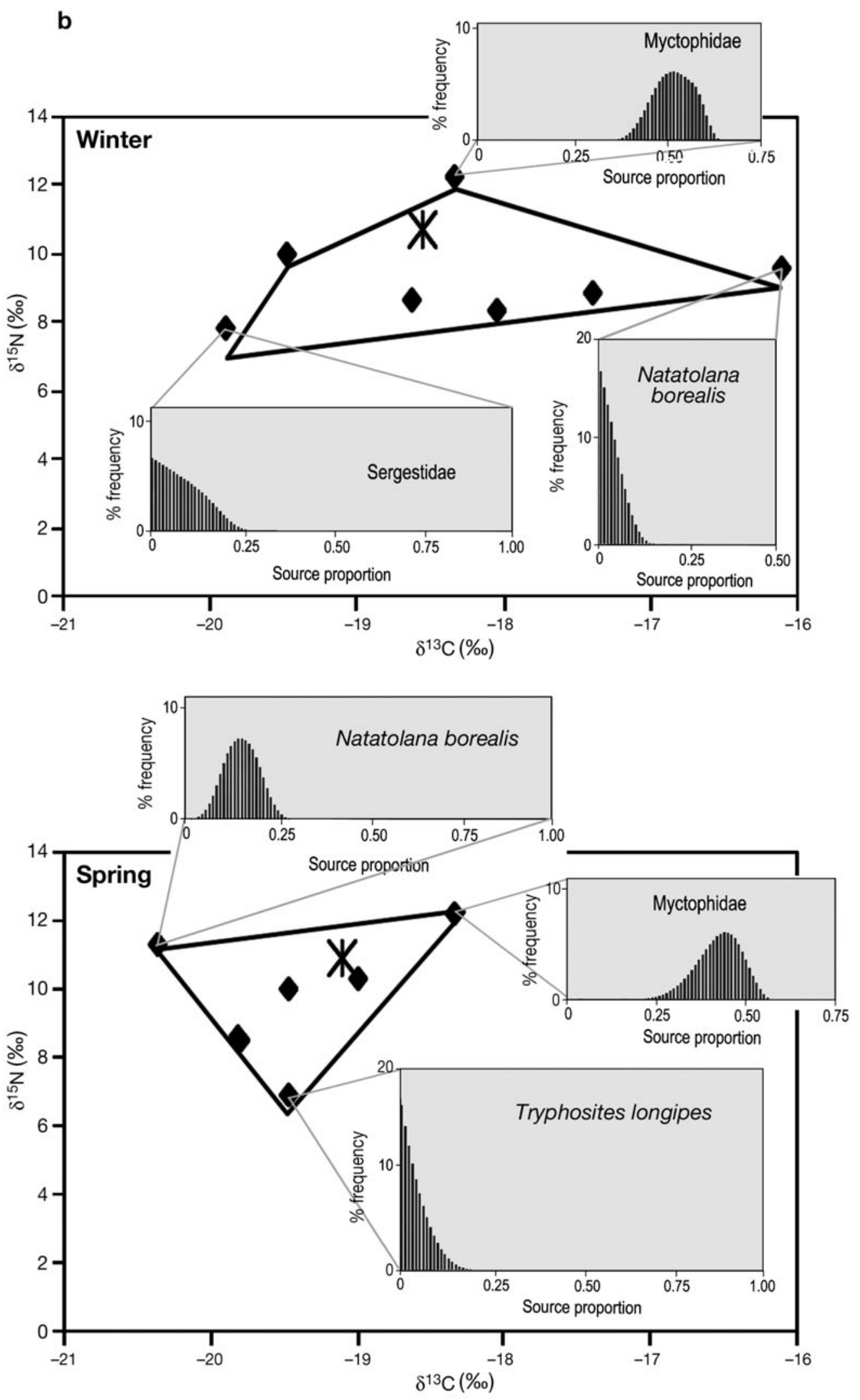

Fig. 4 (continued) 
untreated samples did not show significant differences by month. As for Hymenocephalus italicus, more depleted values, although not significantly, occurred from February to June (Fig. 2b). Significant differences were found among $\delta^{13} \mathrm{C}$ values of normalised samples $\left(F_{5,12}=4.71, \mathrm{p}<0.05\right)$, with August being more enriched than the other months.

The highest correlation for Nezumia aequalis between dietary and tissue $\delta^{15} \mathrm{~N}$ values was obtained when dietary values were correlated with tissue values obtained 2 mo previously (Spearman's $\mathrm{r}=0.86$; $\mathrm{p}<0.05$; see also Fig. 3). Overall the mean $\delta^{15} \mathrm{~N}$ value was $11.19 \%$ $( \pm 0.39)$, corresponding to a trophic level of 5.64 .

The trophic levels calculated by assuming a trophic enrichment of $3.25 \%$ were 4.31 for Hoplostethus mediterraneus, 4.26 for Hymenocephalus italicus and 4.85 for Nezumia aequalis.

\section{Correlations with biotic and abiotic factors}

Stomach fullness of Hoplostethus mediterraneus was significantly correlated with month (Spearman's $\mathrm{r}=$ 0.17, $\mathrm{p}<0.05)$, total length $(\mathrm{r}=-0.21, \mathrm{p}<0.05)$ and weight $(r=-0.29, p<0.01)$ of specimens. Among the explanatory environmental variables, fullness was also correlated with salinity $(\mathrm{r}=-0.88, \mathrm{p}=0.01)$ and the concentration of surface chl a recorded 2 mo before sampling $(\mathrm{r}=-0.94, \mathrm{p}<0.001)$.

Fullness of Hymenocephalus italicus was correlated with PAL $(\mathrm{r}=-0.21, \mathrm{p}<0.01)$ and weight $(\mathrm{r}=-0.21, \mathrm{p}<$ 0.01). Among the environmental variables explored, fullness of $H$. italicus was only correlated with surface chl a concentration recorded 3 mo before sampling began ( $\mathrm{r}=0.94, \mathrm{p}<0.001)$. Weight and PAL of Nezumia aequalis specimens were significantly correlated with fullness $(r=-0.17, p=0.01)$, but fullness was not correlated with any of the environmental variables, although it was negatively correlated with density of specimens (i.e. the total number of specimens collected in each month; $r=-0.83, p=0.04$ ).

\section{DISCUSSION}

\section{Methodological approach}

Our results on the effect of formalin on muscle tissue partially confirmed previous findings. According to published studies (Arrington \& Winemiller 2002, Sarakinos et al. 2002, Sweeting et al. 2004 and references cited therein) our results for the 3 species indicated a minimal effect of formalin on $\delta^{15} \mathrm{~N}$ values after 24 mo (mean formalin effect, $0.27 \pm 0.03 \%$ ). Conversely formalin fixation affected $\delta^{13} \mathrm{C}$ in all 3 species over the period of study and the effect varied among species. In all species there was an increasing depletion with time of preservation (about $2 \%$ in Hoplostethus mediterraneus and Hymenocephalus italicus and $1 \%$ in Nezumia aequalis). This suggests a relationship between species behaviour (i.e. increasing depletion with increasingly pelagic diet and habits) and effects of preservative on $\delta^{13} \mathrm{C}$, which in turn may be related to the lipid content of the species. As observed by Drazen (2007), benthopelagic fishes had significantly larger livers with more lipid, less water and less protein than did benthic fishes; thus, lipid levels may be higher in $H$. mediterraneus, which have strongly pelagic habits, than in macrourids; similarly, lipid levels may be higher in $H$. italicus, a more pelagic feeder, than in $N$. aequalis. Sargent et al. (1983) found similar lipid levels in Hoplostethus atlanticus and $H$. mediterraneus, and Phleger \& Grigor (1990) demonstrated that in $H$. atlanticus the high lipid content, mainly wax-esters, plays an important role in the buoyancy of the species during its vertical displacements. Our results concur with those of other authors (Hobson et al. 1997, Bosley \& Wainright 1999, Arrington \& Winemiller 2002), who found samples preserved in formalin to be more negative (i.e. depleted in $\delta^{13} \mathrm{C}$ ) with respect to controls.

As observed by several authors, formalin may have affected preserved specimens through 2 different mechanisms. The first is selective loss of material from the specimen during preservation. The second is uptake of the preservative into the tissue. Formalin is a carbon-based chemical with a characteristic $\delta^{13} \mathrm{C}$ signature, which is normally depleted with respect to fish tissues. Formalin hydrolyses protein (Hobson et al. 1997, Gloutney \& Hobson 1998, Bosley \& Wainright 1999, Arrington \& Winemiller 2002); thus, we expected depletion of $\delta^{13} \mathrm{C}$ in formalin-preserved specimens, consistent with loss of hydrolysed proteins. However, differences in protein content as well as in lipid content (Arrington \& Winemiller 2002), among our 3 tested fishes, related to their swimming capacity, probably explain the different observed patterns.

Duration of sample preservation and preservative concentration also could affect isotope signatures, and the former appears to have an effect through the first 2 yr of preservation, contrary to other studies (Mullin et al. 1984, Sweeting et al. 2004 and references cited therein), where no effect of preservation duration was found. Although there are several studies on this topic, and almost all point to a clear depletion effect of formalin on $\delta^{13} \mathrm{C}$, certain differences were highlighted in our study compared with others. In our study, the $\mathrm{R}^{2}$ of the observed trends of depletion were 0.48 and 0.66 , excluding Nezumia aequalis. In brackish-water fish, Arrington \& Winemiller (2002) found an $\mathrm{R}^{2}$ value of 0.41 , and in different marine organisms, including 
kelp, Kaehler \& Pakhomov (2001) found an $\mathrm{R}^{2}$ of 0.19 . This suggests that the patterns of variation in $\delta^{13} \mathrm{C}$ depletion are species-specific (Kelly et al. 2006).

With respect to the value of per-step trophic enrichment, $2.54 \%$ as suggested by Vanderklift \& Ponsard (2003) is the most appropriate value to use in this study instead of the widely accepted 3.4\% (Minagawa \& Wada 1984, Post 2002) or 3.25\% (proposed by Vanderklift \& Ponsard 2003 for carnivore vertebrates). In our own data, the per-step trophic enrichment between fish and their diet is $<3 \%$. Hoplostethus mediterraneus has a $\delta^{15} \mathrm{~N}$ value of $10.9 \%$, while its preferred prey in this study (the isopod Natatolana borealis) has a $\delta^{15} \mathrm{~N}$ of $8.10 \%$; Nezumia aequalis has a $\delta^{15} \mathrm{~N}$ value of $11.5 \%$, while among its preferred prey the amphipods of the genus Rhachotropis have a mean $\delta^{15} \mathrm{~N}$ value of $9.13 \%$ (data published in Fanelli et al. 2009). In both cases it is evident that the per-step trophic enrichment is lower than $3.25 \%$ and also lowern than $2.54 \%$ in some cases.

\section{Diet and temporal variations}

Hoplostethus mediterraneus actively foraged on natatory benthopelagic prey, which must be captured in the benthic boundary layer (Angel 1990). The isopod Natatolana borealis was the dominant prey ingested by $H$. mediterraneus on the Algerian Basin slope. This feeding behaviour seemed to be characteristic of the Algerian Basin and may be related to a particular abundance of $N$. borealis in the area (Cartes et al. 2008). Indeed, in other studies, mesopelagic, migrating prey (e.g. natantian decapods mainly belonging to Sergestidae and myctophid fish [Marshall \& Merrett 1977, Du Buit 1978, Merrett \& Marshall 1980, Madurell $\&$ Cartes 2005] and euphausiids [Pais 2002]) dominated the diet. Accordingly, mixing models indicated high consumption by $H$. mediterraneus on myctophids in winter and spring, when a limited number of $H$. mediterraneus were caught.

The overall seasonal changes observed in the relative importance of prey species appear to be related to fluctuations in available prey in the environment and/or to different energy requirements, as has been suggested in several studies of deep-sea fish (e.g. Gordon 1979, Blaber \& Bulman 1987, Madurell \& Cartes 2005, Cartes et al. 2009). Although limited to small specimens (5 to $6 \mathrm{~mm}$, rarely $10 \mathrm{~mm}$ ), our data on suprabenthos and mesozooplankton resources in the area (Cartes et al. 2008, authors' unpubl. data) indicate availability of large isopods throughout the year, even in February and April when they were consumed less, which is consistent with Kaim-Malka's (1997) data from an adjacent area of the Mediterranean slope.
Accordingly, mixing models carried out on stable isotope data for the main potential food sources indicated Natatolana borealis as one of the major food sources in summer and autumn, while mesopelagic fish (e.g. mycthophids) were consumed more in February and April, although these fish seemed to be important prey items throughout the year. Despite the occurrence of mysids (Boreomysis arctica), amphipods (Tryphosites longipes) and natantian decapods (e.g. Sergestidae, Plesionika martia and Pasiphaeidae) in stomach contents, mixing models confirmed they are accessory prey in the diet of Hoplostethus mediterraneus in the Algerian Basin. The shift from almost exclusive consumption of $N$. borealis to predation on mesopelagic fish may be attributed to increased energy requirements before reproduction (see below), since myctophids have a high energetic value (Blaber \& Bulman 1987). H. mediterraneus reaches a reproductive peak in May to September (D'Onghia et al. 1998). This selective shift was confirmed by the large availability of $N$. borealis, which was recorded as abundant throughout the year, and also in February when it was consumed less (Cartes et al. 2008). $H$. mediterraneus may be defined as a specialist feeder.

The 2 macrourids inhabiting mid-bathyal depths in the Algerian Basin, Hymenocephalus italicus and Nezumia aequalis, showed diverse diets that were composed mainly of suprabenthic prey (i.e. amphipods, copepods, ostracods, isopods and cumaceans) and infauna (i.e. polychaetes and tanaids). Macrourid fishes are characteristically described as generalist feeders, with widely diversified diets (Pearcy \& Ambler 1974, Macpherson 1979, Mauchline \& Gordon 1984). This probably constitutes an adaptive advantage in the deep-water, low productivity environments inhabited by macrourids (Pearcy \& Ambler 1974). Previous studies (McLellan 1977, Geistdoerfer 1978, Macpherson 1979) attributed the more benthic behaviour of Nezumia sp. compared with $H$. italicus to differences in mouth morphology (inferior in the former, apical in the latter), and we found in this study that $N$. aequalis preyed more on infaunal organisms (e.g. the tanaid Apseudes spinosus, polychaetes, and the amphipod Maera schmidti) than did H. italicus. Competition may also be reduced by the offset timing of peak abundance depths of the 2 species; $H$. italicus was more abundant at $550 \mathrm{~m}$ (mean $\pm \mathrm{SD}, 1294 \pm 655 \mathrm{ind} . \mathrm{km}^{-2}$ ) than at $750 \mathrm{~m}\left(134 \pm 88\right.$ ind. $\left.\mathrm{km}^{-2}\right)$, while $N$. aequalis centred around $750 \mathrm{~m}\left(916 \pm 253\right.$ ind. $\mathrm{km}^{-2}$, Moranta et al. 2008).

Seasonality in feeding behaviour was correlated to the pelagic or benthic habits of the species. According to previous findings (Haedrich \& Henderson 1974, Mauchline \& Gordon 1984, Drazen et al. 2001) strong seasonal changes in the diet are due to larger seasonal 
fluctuations in pelagic prey compared with benthic prey. Thus, the diet of Hymenocephalus italicus that fed on suprabenthic/pelagic resources showed a stronger seasonal trend than Nezumia aequalis that preyed mainly upon infauna. Infauna is less variable than suprabenthos (BIOMARE project unpubl. data). Changes in diet could be related, apart from seasonal variation in resource availability, to different energetic requirements for reproduction. In the Mediterranean Sea, $N$. aequalis spawns throughout the year (January to February, April to May and October; Carrassón \& Matallanas 1998, Massutí et al. 1995), which could explain the low variation in its dietary composition compared with that of $H$. italicus. In contrast, although mature individuals of $H$. italicus were found throughout the year, ripe females were more abundant in spring and summer (Massutí et al. 1995). Changes in $H$. italicus mainly occurred between November and February, related to a pre-spawning period with different energetic requirements. From February to April, $H$. italicus fed on the more energetic isopods Munnupsurus atlanticus and Natatolana borealis, instead of on mysids, which are low in caloric content (see Cartes et al. 2008). In any case, seasonality was stronger in Hoplostethus mediterraneus than in the 2 macrourids, probably due to its stronger benthopelagic habits and to its more restricted reproductive period.

The relatively high trophic position of Nezumia aequalis (see next paragraph and also Polunin et al. 2001, who found a $\delta^{15} \mathrm{~N}$ of $14.18 \%$ o for this species offshore from Ibiza) is probably due to the high consumption by $N$. aequalis of carnivorous polychaetes (Eunicidae, Aphroditidae, Nepthydae), as suggested by Badalamenti et al. (2002) as an explanation for the high trophic level determined for red mullet Mullus barbatus.

In general, trophic levels calculated by Eq. (2) were higher than those reported in Stergiou \& Karpouzi (2002) based on the TrophLab estimation from the stomach contents analysis reported in literature for the same species. Differences were ca. 1 trophic level for Hoplostethus mediterraneus and Hymenocephalus italicus and up to 1.5 trophic levels for Nezumia aequalis. This may be attributable to the fact that TrophLab does not take into account the high complexity and lengthening of benthic food webs, assigning a high trophic level to prey fish while underestimating benthic carnivores such as polychaetes or suprabenthic amphipods (Fanelli et al. in press).

\section{Temporal variations in trophic levels}

Despite the different feeding behaviour displayed by these 3 deep-sea fishes, a general increase in $\delta^{15} \mathrm{~N}$ values was observed from September to April. For all 3 species, reproduction occurred throughout the year, but the highest percentages of mature individuals were observed in April for the 2 macrourids and in February for Hoplostethus mediterraneus (Massutí et al. 1995, D'Onghia et al. 1998, 1999). An analysis of caloric content of prey in stomachs (Madurell \& Cartes 2005, 2006, Cartes et al. 2008) suggested a peak in energy requirements just before the main reproductive period, as also shown for some decapod crustaceans in the area (Fanelli \& Cartes 2008, Cartes et al. 2008). The increase in $\delta^{15} \mathrm{~N}$ values in February to April could be correlated to predation on more energetic prey before the spawning period, which also corresponded to consumption of prey at higher trophic levels (e.g. decapods and fish in $H$. mediterraneus and isopods in Hymenocephalus italicus). The peak reproductive period is also accompanied by changes in metabolism and increased lipid levels in pre-spawning individuals. Apparently, variations in isotopic composition were not correlated with dietary changes (i.e. did not correspond to prey found in stomachs). However, the expected (dietary) $\delta^{15} \mathrm{~N}$ values were strongly correlated with values obtained from tissues collected after a delay of 1 to 2 mo.

Isotopic turnover rate can be divided into growth and metabolic tissue replacement components (Hesslein et al. 1993, MacAvoy et al. 2001, Maruyama et al. 2001). Maruyama et al. (2001) showed that the contribution of metabolic turnover is important, and hypothesised that the relative contribution of metabolic turnover might be higher in slow-growing than in fast-growing fish. Assuming similar growth, since the study was performed with adult specimens of approximately the same size all year round, the contribution of metabolism (and diet) accounted for most of the nitrogen isotopic change in our study. The turnover time of deep-sea fish that normally live at a temperature of $\sim 13^{\circ} \mathrm{C}$ could be as long as that in some freshwater fishes, e.g., lacustrine Oncorhynchus nerka, in which it was estimated to be ca. 40 d $(80 \%$ turnover rate, Sakano et al. 2005). Tissue turnover depends on the metabolism of each species, and it is expected that there will be higher metabolism (and assimilation of $\delta^{15} \mathrm{~N}$ ) among plankton feeders than in benthos feeders (Koslow 1996). Hence, the synchrony between dietary and tissue $\delta^{15} \mathrm{~N}$ values found in Hoplostethus mediterraneus, and the progressive delay found in more benthic, probably slower growing macrourids, with the highest delay evident in the most benthic species, Nezumia aequalis.

Changes in $\delta^{13} \mathrm{C}$ were stronger in Hoplostethus mediterraneus than in the 2 macrourids. In accordance with high fluctuations in planktonic prey availability, ${ }^{13} \mathrm{C}$ signatures changed more markedly over the year in $H$. mediterraneus than in the macrourids. A similar 
trend was observed for the more pelagic Plesionika martia compared with the more benthic $P$. heterocarpus (Fanelli \& Cartes 2008), suggesting a general response for the entire deep-water community.

\section{Influence of biological and environmental variables}

In the 3 species, stomach fullness was negatively correlated with body length of the fish (and weight in the case of Hoplostethus mediterraneus), which implies that small fish eat relatively more than large fish, probably because of their higher metabolism and energy requirements for growth (Koslow 1996). Only in $H$. mediterraneus was fullness positively correlated to month, which corresponds with the stronger seasonality apparent in its diet and its more pelagic behaviour compared with the 2 macrourid species. The overall seasonal changes observed in the relative importance of preferred prey seem to be related not only to fluctuations in available prey in the environment, as has been suggested in several studies of deep-sea fish (e.g. Gordon 1979, Blaber \& Bulman 1987), but with changes in prey selection (e.g. more energy-rich prey consumed before reproduction). A similar trend was found in deep-sea pandalids (Fanelli \& Cartes 2008), e.g. an increasing influence of seasonality in the pelagic feeder Plesionika martia compared with the more benthic $P$. heterocarpus, and in juvenile Merluccius merluccius compared with adults (Cartes et al. 2009). Again, for the fish we analysed, fullness was correlated to surface primary production recorded during the previous 2 and 3 mo in $H$. mediterraneus and Hymenocephalus italicus, respectively, whilst such relationships were not found for Nezumia aqualis. Therefore, $H$. mediterraneus and $H$. italicus, which are more linked to planktonic prey, and in turn to primary production, were more closely coupled with blooms of primary production than was $N$. aequalis, a strictly benthophagous fish, which probably relates to aspects of their life histories (e.g. recruitment, swarming to spawn). The delay observed between high values of fullness and primary production on the surface may indicate that these deep-sea fishes, at least the benthopelagic species, were mainly linked to the seasonal arrival of particulate organic matter (POM) at the seabed from the surface around the Balearic Islands.

In contrast to the Catalonian slope (Cartes et al. 2009) where strong cascade fluxes occur and are channelled through submarine canyons, the Algerian Basin south of the Balearic Islands is an insular area with little influence from advective inputs (Cartes et al. 2008). Thus, POM arriving at the seabed is mainly of marine origin and vertically transported as phytodetritus from the surface (Fanelli et al. 2009). In the pelagic domain, a de- lay between peaks of phytoplankton blooms and krill was suggested by different investigators in the North Sea (Noji 1991, Dam et al. 1993) and has also been observed in the bathyal domain of the Algerian Basin (Cartes et al. 2008, Fanelli \& Cartes 2008). Fullness in Hoplostethus mediterraneus was also correlated with an increase in salinity, which could imply a relationship between this species and changes in water masses, i.e. it seems that the presence of this species in the Algerian Basin was mainly linked to Levantine intermediate waters. Consistently, H. mediterraneus abundance decreases dramatically from February to June. During August and September 2003, an anticyclonic gyre was present in the Gulf of Valencia, which produced a branch of the Balearic Current flowing inside the Mallorca Channel, with distinct winter intermediate water and Levantine intermediate water values (Lopez-Jurado et al. 2008). Correlations with salinity close to the seabed suggest a link between food consumption of $H$. mediterraneus (increment from August to November) and changes in water masses.

In conclusion, deep-sea fishes around the Balearic Islands are subjected to intra-annual variability in environmental conditions of both a trophic (primary production) and an oceanographic (water masses) nature. In addition, this environmental variability seems to have a higher and more rapid influence in species belonging to low trophic levels that consume pelagic prey species than among benthos feeders situated at the top of deep-sea trophic webs.

Acknowledgements. We greatly appreciate the help of all participants in the IDEA cruises, of the crews of the FV 'Moralti Nou' and the RV 'Fco. De Paula Navarro'. We warmly thank our colleagues J. Moranta, E. Massutí and B. Pomar for their assistance on board. We especially acknowledge the assistance of Drs. P. Rumolo and M. Sprovieri (CNR-IAMC of Naples) in the stable isotope analyses and Dr. D. L. Phillips for the helpful suggestions in the use of IsoSource. We also acknowledge 3 anonymous referees who greatly improved the original version of the manuscript.

\section{LITERATURE CITED}

Anderson MJ, Gorley RN, Clarke KR (2008) PERMANOVA+ for PRIMER: guide to software and statistical methods. PRIMER-E, Plymouth

Angel MV (1990) Life in the benthic boundary layer: connections to the mid-water and sea floor. Philos Trans R Soc Lond 331:15-28

Arrington AD, Winemiller KO (2002) Preservation effects on stable isotope analysis of fish muscle. Trans Am Fish Soc 131:337-342

> Atkinson A (1995) Omnivory and feeding selectivity in five copepod species during spring in the Bellingshausen Sea, Antarctica. ICES J Mar Sci 52:385-396

> Badalamenti F, D'Anna G, Pinnegar J, Polunin N (2002) Sizerelated trophodynamic changes in three target fish species recovering from intensive trawling. Mar Biol 141: $561-570$ 
Billett DSM, Lampitt RS, Rice AL, Mantoura RFC (1983) Seasonal sedimentation of phytoplankton to the deep-sea benthos. Nature 302:520-522

Blaber SJM, Bulman CM (1987) Diets of fishes of the upper continental slope of eastern Tasmania: content, calorific values, dietary overlap and trophic relationships. Mar Biol 95:345-356

Bosley KL, Wainright SC (1999) Effects of preservatives and acidification on the stable isotope ratios $\left({ }^{15} \mathrm{~N}:{ }^{14} \mathrm{~N},{ }^{13} \mathrm{C}:{ }^{12} \mathrm{C}\right)$ of two species of marine animals. Can J Fish Aquat Sci 56: $2181-2185$

Carpine C (1970). Ecologie de l'étage bathyal dans la Méditerranée occidentale. Mem Inst Oceanogr Monaco 2: $1-146$

Carrassón M, Cartes JE (2002) Trophic relationships in a Mediterranean deep-sea fish community: partition of food resources, dietary overlap and connections within the benthic boundary layer. Mar Ecol Prog Ser 241: 41-55

> Carrassón M, Matallanas J (1998) Feeding habits of Alepocephalus rostratus (Pisces: Alepocephalidae) in the western Mediterranean Sea. J Mar Biol Assoc UK 78: 1295-1306

Carrassón M, Matallanas J (2002) Diets of deep-sea macrourid fishes in the western Mediterranean. Mar Ecol Prog Ser 234:215-228

Carrassón M, Stefanescu C, Cartes JE (1992) Diets and bathymetric distributions of two bathyal sharks of the Catalan deep sea (western Mediterranean). Mar Ecol Prog Ser 82: 21-30

Cartes JE (1994) Influence of depth and season on the diet of the deep-water aristeid Aristeus antennatus along the continental slope (between 400 to $2300 \mathrm{~m}$ ) in the Catalan Sea (western Mediterranean). Mar Biol 120:639-648

Cartes JE (1998) Dynamics of the bathyal benthic boundary layer in the northwestern Mediterranean: depth and temporal variations in macrofaunal-megafaunal communities and their possible connections within deep-sea trophic webs. Prog Oceanogr 41:111-139

Cartes J, Grémare A, Maynou F, Villora-Moreno S, Dinet A (2002) Bathymetric changes in the distribution of particulate organic matter and associated fauna along a deep-sea transect down the Catalan sea slope (Northwestern Mediterranean). Prog Oceanogr 53:29-56

> Cartes JE, Papiol V, Guijarro B (2008) The feeding and diet of the deep-sea shrimp Aristeus antennatus off the Balearic Islands (Western Mediterranean): influence of environmental factors and relationship with the biological cycle. Prog Oceanogr 79:37-54

Cartes JE, Hidalgo M, Papiol V, Massutí E, Moranta J (2009) Changes in the diet and feeding of the hake Merluccius merluccius at the shelf-break of the Balearic Islands: influence of the mesopelagic-boundary community. Deep-Sea Res I 56:344-365

- Cattrijsse A, Makwaia ES, Dankwa HR, Hamerlynck O, Hemminga MA (1994) Nekton communities of an intertidal creek of a European estuarine brackish marsh. Mar Ecol Prog Ser 109:195-208

Clarke KR (1993) Non-parametric multivariate analyses of changes in community structure. Aust J Ecol 18:117-143

Clarke KR, Warwick RM (1995) Change in marine communities: an approach to statistical analysis and interpretation. Natural Environment Research Council, Plymouth

> Clarke LR, Vidergar DT, Bennett DH (2005) Stable isotopes and gut content show diet overlap among native and introduced piscivores in a large oligotrophic lake. Ecol Freshw Fish 14:267-277
D'Onghia G, Tursi A, Marano CA, Basanisi M (1998) Life history traits of Hoplostethus mediterraneus (Pisces: Beryciformes) from the north-western Ionian Sea (Mediterranean Sea). J Mar Biol Assoc UK 78:321-339

- D'Onghia G, Basanisi M, Matarrese A, Megli CA (1999) Reproductive strategies in macrourid fish: seasonality or not? Mar Ecol Prog Ser 184:189-196

Dam HG, Miller CA, Jonasdottir SH (1993) The trophic role of mesozooplankton at $47^{\circ} \mathrm{N}, 20^{\circ} \mathrm{W}$ during the North Atlantic Bloom Experiment. Deep-Sea Res II 40:197-212

> Drazen JC (2007) Depth related trends in proximate composition of demersal fishes in the eastern North Pacific. Deep Sea Res I 54:203-219

> Drazen JC, Buckley TW, Hoff GR (2001) The feeding habits of slope dwelling macrourid fishes in the eastern North Pacific. Deep-Sea Res I 48:909-935

Du Buit ME (1978) Alimentation de quelques poissons téléostéens de profondeur dans la zone du seuil de Wyville Thomson. Oceanol Acta 1:129-134

> Edwards MS, Turner TF, Sharp ZD (2002) Short- and longterm effects of fixation and preservation on stable isotope values $\left(\delta^{13} \mathrm{C}, \delta^{15} \mathrm{~N}, \delta^{34} \mathrm{~S}\right)$ of fluid-preserved museum specimens. Copeia 2002:1106-1112

Fanelli E, Cartes JE (2008) Spatio-temporal changes in gut contents and stable isotopes in two deep Mediterranean pandalids: influence on the reproductive cycle. Mar Ecol Prog Ser 355:219-233

Fanelli E, Cartes JE, Rumolo P, Sprovieri M (2009) Food web structure and trophodynamics of mesopelagic-suprabenthic deep sea macrofauna of the Algerian basin (Western Mediterranean) based on stable isotopes of carbon and nitrogen. Deep-Sea Res I 56:1504-1520

Fanelli E, Badalamenti F, D'Anna G, Pipitone P, Romano C (in press) Trophodynamic effects of trawling on the feeding ecology of pandora, Pagellus erythrinus, off the northern Sicily coast (Mediterranean Sea). Mar Freshw Res

Ferry LA, Caillet GM (1996) Sample size and data analysis: Are we characterizing and comparing diet properly? In: MacKinlay D, Shearer K (eds) Feeding ecology and nutrition in fish. Symp Proc. American Fisheries Society, San Francisco, CA, p 71-80

Feuchtmayr H, Grey J (2003) Effect of preparation and preservation procedures on carbon and nitrogen stable isotope determinations from zooplankton. Rapid Commun Mass Spectrom 17:2605-2610

Gartner JV, Crabtree RE, Sulak KJ (1997) Feeding at depth. In: Randall DJ, Farrell AP (eds) Deep-sea fishes. Fish physiology, Vol 16. Academic Press, New York, p 115-193

Geistdoerfer P (1978) Ecology alimentaire des Macrouridae. Rev Trav Off Scient Tech Pech Marit 42:177-260

Gloutney ML, Hobson KA (1998) Field preservation techniques for the analysis of stable carbon and nitrogen isotope ratios in eggs. J Field Ornithol 69:223-227

> Gooday AJ (1988) A response by benthic Foraminifera to the deposition of phytodetritus in the deep sea. Nature 332:70-73

Gordon JDM (1979) Lifestyle and phenology in deep sea anacanthine teleosts. Symp Zool Soc Lond 44:327-359

Haedrich RL, Henderson NR (1974) Pelagic food of Coryphaenoides armatus, a deep benthic rattail. Deep-Sea Res 21:739-744

> Harvey C, Hanson P, Essington T, Brown P, Kitchell J (2002) Using bioenergetics models to predict stable isotope ratios in fishes. Can J Fish Aquat Sci 59:115-124

> Herzka SZ, Holt GJ (2000) Changes in isotopic composition of red drum (Sciaenops ocellatus) larvae in response to dietary shifts: potential applications to settlement studies. Can J Fish Aquat Sci 57:137-147 
Hesslein RH, Hallard KA, Ramlal P (1993) Replacement of sulfur, carbon, and nitrogen in tissue of growing broad whitefish (Coregonus nasus) in response to a change in diet traced by $\delta^{34} \mathrm{~S}, \delta^{13} \mathrm{C}$, and $\delta^{15} \mathrm{~N}$. Can J Fish Aquat Sci 50 : 2071-2076

Hobson KA, Gibbs HL, Gloutney ML (1997) Preservation of blood and tissue samples for stable-carbon and stablenitrogen isotope analysis. Can J Zool 75:1720-1723

Hyslop EJ (1980) Stomach contents analysis-a review of methods and their application. J Fish Biol 17:411-429

Johnston AM, Kennedy H (1998) Carbon stable isotope fractionation in marine systems: open ocean studies and laboratory studies. In: Griffiths H (ed) Stable isotopes: integration of biological, geological and geochemical processes. BIOS Scientific Publishers, Oxford, p 239-256

Kaehler S, Pakhomov EA (2001) Effects of storage and preservation on the $\delta^{13} \mathrm{C}$ and $\delta^{15} \mathrm{~N}$ signatures of selected marine organisms. Mar Ecol Prog Ser 219:299-304

Kaim-Malka R (1997) Biology and life cycle of Natatolana borealis Lilj. 1851, a scavenging isopod from the continental slope of the Mediterranean. Deep-Sea Res I 44: 2045-2067

Kelly B, Dempson JB, Power M (2006) The effects of preservation on fish tissue stable isotope signatures. J Fish Biol 69: 1595-1611

Koslow JA (1996) Energetic and life-history patterns of deepsea benthic, benthopelagic and seamount-associated fish. J Fish Biol 49(Suppl A):54-74

Lopez-Jurado JL, Marcos M, Monserrat S (2008) Hydrographic conditions during the IDEA project (2003-2004). J Mar Syst 71(3-4):303-315

Lubetkin SC, Simenstad CA (2004) Multi-source mixing models to quantify food web sources and pathways. J Appl Ecol 41:996-1008

MacAvoy SE, Macko SA, Garman G (2001) Isotopic turnover in aquatic predators: quantifying the exploitation of migratory prey. Can J Fish Aquat Sci 58:923-932

MacNeil M, Drouillard K, Fisk A (2006) Variable uptake and elimination of stable nitrogen isotopes. Can J Fish Aquat Sci 63:345-353

> Macpherson E (1979) Ecological overlap between macrourids in the western Mediterranean Sea. Mar Biol 53:149-159

Macpherson E (1980) Régime alimentaire de Galeus melastomus Rafinesque, 1810 Etmpoterus spinax (L., 1758) et Scymnorhinchus licha (Bonnaterre, 1788) en Méditerranée occidentale. Vie Milieu 30:139-148

Macpherson E (1981) Resource partitioning in a Mediterranean demersal fish community. Mar Ecol Prog Ser 4: 183-193

Madurell T, Cartes JE (2005) Temporal changes in feeding habits and daily rations of Hoplostethus mediterraneus, Cuvier, 1829 in the bathyal Ionian Sea (eastern Mediterranean). Mar Biol 146:951-962

Madurell T, Cartes JE (2006) Trophic relationships and food consumption of slope dwelling macrourids from bathyal Ionian Sea (eastern Mediterranean). Mar Biol 148: 1325-1338

Madurell T, Fanelli E, Cartes JE (2008) Isotopic composition of carbon and nitrogen of suprabenthos fauna in the NW Balearic Islands (Western Mediterranean). J Mar Syst 71: 336-345

Margalef R (1985) Environmental control of the mesoscale distribution of primary producers and its bearing to primary production in the Western Mediterranean. In: Moraitou-Apostolopoulou M, Kiortsis V (eds) Mediterranean marine ecosystems. Ecol ser 1. Plenum Press, New York, p 247-277
Marshall NB, Merrett NR (1977) The existence of a benthopelagic fauna in the deep-sea. Deep-Sea Res I 24(Suppl):483-497

> Maruyama A, Yamada Y, Rusuwa B, Yuma M (2001) Change in stable nitrogen isotope ratio in the muscle tissue of a migratory goby, Rhinogobius sp., in a natural setting. Can J Fish Aquat Sci 58:2125-2128

Massutí E, Moranta J, Gordon JDM, Morales-Nin B, Oliver P (2008) The wrapping up of the IDEA project. International workshop on environment, demersal resources and fisheries. J Mar Syst 71:221-222

Massutí E, Reñones O (2005) Demersal resource assemblages in the trawl fishing grounds off the Balearic Islands (western Mediterranean). Sci Mar 69:167-181

Massutí E, Morales-Nin B, Stefanescu C (1995) Distribution and biology of five grenadier fish (Pisces: Macrouridae) from the upper and middle slope of the northwestern Mediterranean. Deep-Sea Res 42:307-330

Mauchline J, Gordon JDM (1984) Diets and bathymetric distributions of the macrourid fish of the Rockall Trough, northeastern Atlantic Ocean. Mar Biol 81:107-121

> Mauchline J, Gordon JDM (1986) Foraging strategies of deep-sea fish. Mar Ecol Prog Ser 27:227-238

McLellan T (1977) Feeding strategies of the macrourids. Deep-Sea Res 24:1019-1036

Merrett NR, Marshall NB (1980) Observations on the ecology of deep sea bottom living fishes collected off northwest Africa $\left(08^{\circ}-27^{\circ} \mathrm{N}\right)$. Prog Oceanogr 9:185-244

Minagawa M, Wada E (1984) Stepwise enrichment of $\delta^{15} \mathrm{~N}$ along food chains: further evidence and the relation between $\delta^{15} \mathrm{~N}$ and animal age. Geochim Cosmochim Acta 48:1135-1140

Moranta J, Quetglas A, Massutí E, Guijarro B, Hidalgo M, Diaz P (2008) Spatio-temporal variations in deep-sea demersal communities off the Balearic Islands (western Mediterranean). J Mar Syst 71:346-366

Mullin MM, Rau GH, Eppley RW (1984) Stable nitrogen isotopes in zooplankton: some geographic and temporal variation in the North Pacific. Limnol Oceanogr 29:1267-1273

Noji TT (1991) The influence of macrozooplankton on vertical particulate flux. Sarsia 76:1-9

Owens NJP (1988) Natural variations in ${ }^{15} \mathrm{~N}$ in the marine environment. Adv Mar Biol 24:389-451

Owens NJP, Watts LJ (1998) The assimilation of nitrogen by marine phytoplankton and the role of ${ }^{15} \mathrm{~N}$ : the past, present and future? In: Griffiths H (ed) Stable isotopes: integration of biological, geological and geochemical processes. BIOS Scientific Publishers, Oxford, p 257-277

Pais C (2002) Diet of a deep-sea fish, Hoplostethus mediterraneus. J Mar Biol Assoc UK 82:351-352

Pearcy WG, Ambler LW (1974) Food habits of deep-sea macrourid fishes off the Oregon coast. Deep-Sea Res 21: 745-759

Phillips DL, Gregg JW (2003) Source partitioning using stable isotopes: coping with too many sources. Oecologia 136: 261-269

> Phleger CE, Grigor MR (1990) Role of wax esters in determining buoyancy in Hoplostethus atlanticus (Beryciformes: Trachichthyidae). Mar Biol 105:229-233

Pinnegar JK, Polunin NVC (2000) Contributions of stable isotope data to elucidating food webs of Mediterranean rocky littoral fishes. Oecologia 122:399-409

Polunin NVC, Morales-Nin B, Herod W, Cartes JE, Pinnegar JK, Moranta J (2001) Feeding relationships in Mediterranean bathyal assemblages elucidated by carbon and nitrogen stable-isotope data. Mar Ecol Prog Ser 220: 13-23 
Post DM (2002) Using stable isotopes to estimate trophic position: models, methods, and assumptions. Ecology 83: 703-718

Post DM, Layman CA, Arrington DA, Takimoto G, Quattrochi J, Montaña CJ (2007) Getting to the fat of the matter: models, methods and assumptions for dealing with lipids in stable isotope analyses. Oecologia 152:179-189

Priede IG, Bagley PM, Smith A, Creasey S, Merrett NR (1994) Scavenging deep demersal fishes of the Porcupine Seabight, Northeast Atlantic-observations by baited camera, trap and trawl. J Mar Biol Assoc UK 74: 481-498

Rice AL, Thurston MJH, Bett BJ (1994) The IOSDL DEEPSEAS program: introduction and photographic evidence for the presence and absence of a seasonal input of phytodetritus at contrasting abyssal sites in the northeastern Atlantic. Deep-Sea Res 41:1305-1320

Rosecchi E, Tracey DM, Webber WR (1988) Diet of orange roughy, Hoplostethus atlanticus (Pisces: Trachichthyidae), on the Challenger Plateau, New Zealand. Mar Biol 99: 293-306

Sakano H, Fujiwara E, Nohara S, Ueda H (2005) Estimation of nitrogen stable isotope turnover rate of Oncorhynchus nerka. Environ Biol Fishes 72:13-18

Sarakinos HC, Johnson ML, Vander Zanden MJ (2002) A synthesis of tissue-preservation effects on carbon and nitrogen stable isotope signatures. Can J Zool 80:381-387

Sargent JR, Gatten RR, Merret NR (1983) Lipids of Hoplo-

Editorial responsibility: Konstantinos Stergiou, Thessaloniki, Greece stethus atlanticus and $H$. mediterraneus (Beryciformes: Trachichthyidae) from deep water to the west of Britain. Mar Biol 74:281-286

Stergiou KI, Karpouzi VS (2002) Feeding habits and trophic levels of Mediterranean fishes. Rev Fish Biol Fish 11: $217-254$

Sweeting CJ, Polunin NV, Jennings S (2004) Tissue and fixative dependent shifts of $\delta^{13} \mathrm{C}$ and $\delta^{15} \mathrm{~N}$ in preserved ecological material. Rapid Commun Mass Spectrom 18: 2587-2592

Syväranta J, Vesala S, Rask M, Ruuhijärvi J, Jones RI (2008) Evaluating the utility of stable isotope analyses of archived freshwater sample materials. Hydrobiologia 600: 121-130

Thiel H, Pfannkuche O, Schrieber K, Lochte K and others (1989) Phytodetritus on the deep-sea floor in a central oceanic region of the Northeast Atlantic. Biol Oceanogr 6: 203-239

Underwood AJ (1997) Experiments in ecology: their logical design and interpretation using analysis of variance. Cambridge University Press, Cambridge

Vander Zanden MJ, Chandra S, Allen BC, Reuter JE, Goldman R (2003) Historical food web structure and restoration of native aquatic communities in the Lake Tahoe (California-Nevada) Basin. Ecosystems 6:274-288

Vanderklift MA, Ponsard S (2003) Sources of variation in consumer-diet $\delta^{15} \mathrm{~N}$ enrichment: a meta-analysis. Oecologia 136:169-182

Submitted: April 30, 2009; Accepted: November 16, 2009 Proofs received from author(s): February 5, 2010 